\title{
About time: toward a sequencing of the Dampier Archipelago petroglyphs of the Pilbara region, Western Australia
}

\author{
K. Mulvaney \\ Specialist Cultural Heritage, Rio Tinto, Dampier, Western Australia; \\ Adjunct Lecturer, University of Western Australia, Nedlands, Western Australia 6009, Australia.
}

\begin{abstract}
Since the early 1970s the petroglyphs of the Dampier Archipelago have been acknowledged for their National and World heritage status. Part of this recognition of significance is the evident antiquity, stylistic variability and abundance of production that the petroglyphs display. It has been suggested that the oldest of these images are in the order of 15,000 to 18,000 years old. Based on only a few dates, coupled with stylistic and weathering patterns, a three-phase art sequence was first put forward in the early 1980s. These identified art phases were defined on information collected from just two locations toward the southern end of Dampier Island. This paper presents a more comprehensive temporal structure to the Dampier rock art. Unlike previous studies, which focussed on a restricted survey area, this current study draws on knowledge of a larger and more widely distributed sample of the rock art. The results suggest at least five major art phases spanning some 20 to 30,000 years.
\end{abstract}

KEYWORDS: rock art, chronology, patination

\section{INTRODUCTION}

Four large turtle engravings are positioned on the rocky foreshore to the south of Withnell Bay, Dampier Island, in the Pilbara Region of Western Australia (Figure 1). These images are unlike any other turtle images or other marine subjects depicted in the petroglyphs of the Dampier Archipelago. Over 30 years ago, Sylvia Hallam (pers. comm. 1980) postulated that these marine influenced petroglyphs predated the current coastal environment of the location, and thus must be of remarkable antiquity. A long standing champion of an ancient pedigree for the rock art of the Dampier Archipelago, Sylvia Hallam has consistently urged a better understanding of the archaeological significance of this region's rock art. Although not quite to the extent Sylvia Hallam envisaged, nonetheless it is now likely that the petroglyphs of the Dampier Archipelago extend back into the Last Glacial Maximum (LGM), beyond 20,000 years ago.

The Dampier Archipelago is situated on the northwest coast of Western Australia, at latitude 20 $30^{\prime} \mathrm{S}$, some $300 \mathrm{~km}$ north of the Tropic of Capricorn (Figure 2). Today it is an area strongly influenced by episodic cyclonic winds and rain. It is rich in subsistence resources, as the massive and numerous shell middens and artefact scatters attest. It is also known for the proliferation of engraved rock art (petroglyphs) and stone arrangements. Dampier
Island is the largest of the 42 islands and rocky outcrops that form the Dampier Archipelago. The Burrup Peninsula is the name by which Dampier Island is now known, a result of industrial developments in the late 1960s that effectively removed the tidal, mangrove lined, mudflats separating the island from the mainland. The area is remarkable for the vast stylistic diversity (subject, technique and artistic form) of the petroglyphs. Rock art covers the whole landscape of the Archipelago and occurs within the context of subsistence areas, ritual activities and mythological sites.

The main rock on which the petroglyphs occur is heavily jointed and fractured gabbro and granophyre, both igneous rocks; on the eastern margin of the Burrup Peninsula and on some of the island porphyritic granite and granodiorite is exposed (Hickman 2001). This has weathered into extensive block structures that give the impression of massive dumps and rock piles, with some areas of granite domes and outcropping boulders. Granophyre is extremely hard; it is blue-grey to greenish-grey in colour and weathers through a reddish-brown to dark brown on the crust. It is these colour contrasts between the weathered and the freshly created surfaces that give visibility to the petroglyphs. The blocky formation of the granophyres, and the hardness of the rock coupled with its stable structure mean it does not fracture 
or crumble as fast as other rocks, like sandstones or granites, a feature that has ensured the long term preservation of the petroglyphs.

\section{DAMPIER ARCHIPELAGO PETROGLYPHS}

In what is recognised as Yaburara country, the Dampier Archipelago contains arguably the greatest concentration of petroglyphs in the world. It is the particular petrology and geomorphology of the area that lends itself to this proliferation. Rock art is found throughout all the islands; however, Dampier Island (the largest island $118 \mathrm{~km}^{2}$ - now Burrup Peninsula) and the other near coastal islands have by far the greater numbers and diversity. To date there has not been a comprehensive survey of the Dampier Archipelago rock art and the total number of petroglyphs and rock art sites is not known, although it has been estimated that there could be as many as 6,000 sites and more than 500,000 petroglyphs, possibly up to one million (McDonald and Veth 2005; Bednarik 2006). It is in the deeply dissected gullies with associated rock pools and the massive tumbled block slopes that the major sites are found. Many of the valleys on Dampier Island each contain tens of thousands of rock art images (Virili 1977; DAS 1984; Lorblanchet 1992; Veth et al. 1993; Vinnicombe 2002). Although there is a clear association of the major rock art concentrations with rock pools within the granophyre valleys, there are

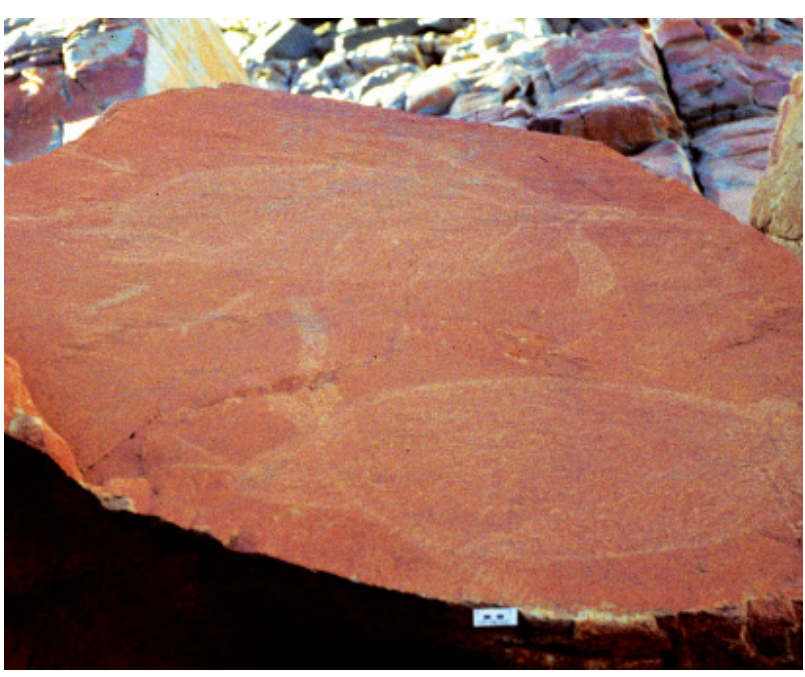

FIGURE $1 \quad$ Large turtle images on the rocky shore at Withnell Bay. (Photo supplied by Department of Indigenous Affairs.)

also concentrations of petroglyphs in proximity to specific resource locations, such as mangrove lined creeks and sandy beaches.

An additional feature of the Dampier Archipelago rock art is the range of techniques utilised in producing the images (Veth et al. 1993; Vinnicombe 2002; Gunn 2004, 2007), although pecking out the weathered crust is the most common (about $60-90 \%$ ). Different forms of the image are produced through the impact depth and density of the
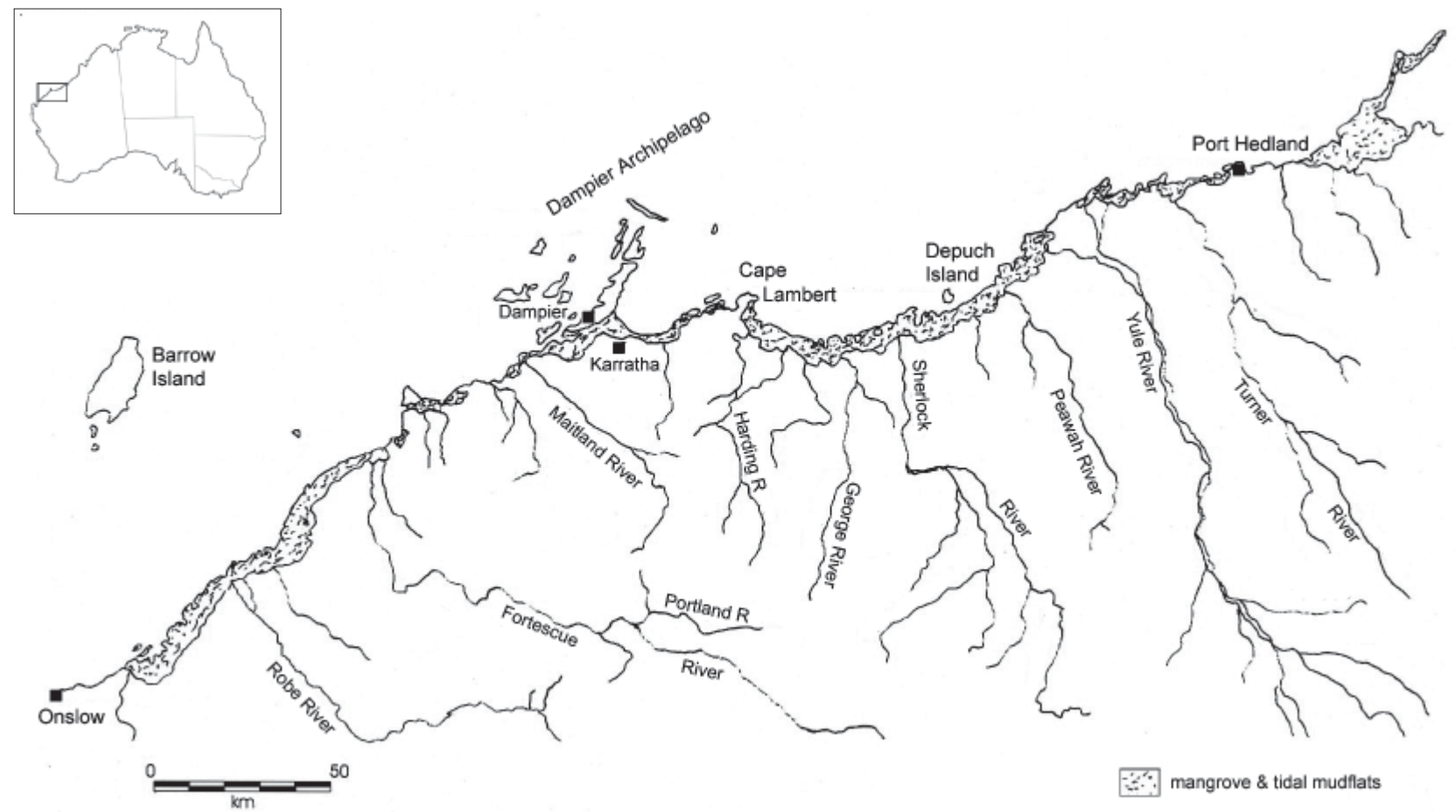
pecking, ranging from deep linear grooves to separated, irregularly-spaced, shallow pecks. Bruising (pounding) and abrading are less common, as is scoring (scratching). These latter techniques produce much shallower images, in some cases making them difficult to see, although they would have been highly visible when they were first produced, as is attested by recent graffiti. This low visibility may account for the variation in recorded percentage of this technique from $42 \%$ to as low as $10 \%$ observed in different locations during the detailed surveys that have been carried out (Veth et al. 1993; Vinnicombe 2002; Gunn 2004). However, it is also possible that the different percentages may result from genuine variations in distributions rather than observer variability or differences in completeness of recording.

Petroglyphs of the Dampier Archipelago can be grouped into a number of motif subject classes. The main divisions are those of geometric designs, tracks and figurative images. Geometric images range from simple designs to complex images combining a number of geometric elements. Of the figurative (naturalistic) group, human figures, including anthropomorphs, comprise a varied and diverse group of images (see McDonald and Veth 2005). Vinnicombe (2002: 17) identified that, of the animal species, turtles are the most common, followed by fish, and then equal representation of macropods, birds and reptiles. Some of the other animal subjects repeated in the rock art include quadrupeds (including thylacine), echidna, crustaceans and stingray.

Distribution of motifs is variable; some images are found throughout the islands while distinct anthropomorphic and therianthropic (animal/ human combination) images may be specific to particular locations.

Radiocarbon determinations from the archaeological excavations conducted at the Skew Valley site show that the consumption of the shellfish Terebralia palustris occurred between c. 7,000 to 4,500 $\mathrm{BP}$ and that of Anadara granosa c. 4,500 to 2,000 BP (Lorblanchet 1983, 1992). Subsequent data from excavations throughout the archipelago support these initial findings (Vinnicombe 1987; Bradshaw 1995). In addition, geophysical studies indicate the establishment of a marine ecosystem, thus the formation of the archipelago, at about 7,000 BP. The trumpet shell radiocarbon dated to about 18,000 BP at Gum Tree Valley (Lorblanchet 1992: 42) suggests people were present in the area at the time of the LGM. It is these two major climatic and environment events, the LGM and marine transgression, which provide the chronological pegs on which to hang the Dampier rock art sequence.

\section{CHRONOLOGICAL ISSUES}

It is true that rock art, especially petroglyphs, offers little in the way of absolute dating. Nevertheless chronological indicators do exist. During excavations at Skew Valley, a site located toward the southern end of Dampier Island, five pieces of engraved rock were recovered, providing for minimum dates, based on radiocarbon age determinations, of $3,700 \mathrm{BP}$ for a group of side profile human figures, 2,700 BP for simple stick figures and 2,600 BP for a 'coiled snake' (Lorblanchet 1992: 41). In addition, Lorblanchet investigated the spatial relationship of particular stylistic and subject patterns within the rock art and their proximity to the midden. He assumed some of the variation related to his 'gastropod gatherers', while other images, the relatively fresh engravings, were done by his 'bivalves gatherers' (Lorblanchet 1992: 43). At the Gum Tree Valley location $(1,100 \mathrm{~m}$ to the south of Skew Valley), Lorblanchet recognised a group of petroglyph subjects that are ubiquitous and produced over a long period of time. This he based on a radiocarbon date of $18,000 \mathrm{BP}$ for a trumpet shell fragment situated in a rock crevasse between engraved blocks.

Dating of oxalate crusts and other mineral coatings that may trap organic particles has been applied successfully in relation to Australia rock art (see Dorn 2001 for comment). Currently no oxalate formations have been observed within the Dampier Archipelago, however, a mineral coating known as 'desert varnish' is a potential chronological indicator (Clarke 1978; Mulvaney 1982; see also Dragovich 1986, 2000). It was believed that conditions suitable for formation of such varnish prevailed during the hyper-arid phase associated with the LGM; unfortunately, attempts to obtain viable dates from samples submitted have proved elusive (Allan Watchman pers. comm. 2004).

Colour contrast between the engraved and adjacent surface is determined by the thickness of the weathered crust, depth of image indentation, and, most relevant, the time since image creation (Bednarik 1979/80). It is the gradual repatination (weathering) of the image's formed surface that provides a useful indicator of time passing. The degree of patination (colour contrast) is used in this paper as an aid to formulate the chronological sequence of the Dampier Archipelago's rock art. In general petroglyphs can be assigned into one of three groups; fully-patinated; un-patinated; and those that fall between, 'half-patinated' (Gunn 2003). A slightly more complex contrast categorization was implemented during the original survey recording work associated with Woodside's on-shore Liquefied Natural Gas plant development (DAS 1984; Vinnicombe 1987). In Lorblanchet's investigation of the Gum Tree Valley sites, he used a Mastersix- 
Goessen photo-electric cell for light metre calibration rather than relying solely on the subjective visual appearance of the engravings (Lorblanchet 1992: 43).

The shallowness and consequent near invisibility of the scratched motifs also presents a complication in assigning a date to the utilisation of this technique. Patination and contrast indices do not readily apply to this type of image; coupling this with the possible inconsistency of recording presents particular problems. It may also be of relevance that many of the scored images are fish or simple linear geometric figures. In design these forms lend themselves to this particular technique of production and may not have been utilised earlier than when such subjects became abundant, both in the environment and the art.

There are a number of distinct features that are present in petroglyphs that are relatively fresh, with no repatination. One of these aspects is the appearance of stick figures/simple human forms with 'ceremonial' associations (head-dress; objects; group positions). These ceremonial scenes, especially the associated objects, have identifiable links to the ethnography and to contemporary ritual practices. A second development is in the composite panels comprising human and fauna in what can be interpreted as hunting scene depictions. This includes spearing and possible line fishing, and the use of 'nets' to corral dugong. Both the link with contemporary culture and the association with marine subjects confirm the relatively young age that the physical condition and location of these petroglyphs indicate.

The absence of cupules in the earliest art phase proposed for the Dampier Archipelago is an anomaly in the general sequence of Australian rock art. Cupules (small pecked/pounded pits) are a feature of most early sites within Australia and other parts of the world (Chaloupka 1992; Walsh 1994; Flood 1997; Taçon et al. 1997; Morwood 2002). Where cupules occur within the Dampier Archipelago they are as small clusters on exposed block surfaces. This is in contrast to the general pattern within Australia where they cover large areas of wall within rock shelters and small caves, or over boulder surfaces within such locations. It may be the lack of such physiographic loci that accounts for their absence in the oldest art. However, as an image form they persist into the more recent rock art phases where they are interpreted as turtle egg depictions.

There are two aspects of the Dampier Archipelago rock art that complicate the ability to confirm temporal patterns. First, there is the paucity of superimposition; either artists respected the works of predecessors or the abundance of rock surfaces reduced the occurrence of overlap. Superimposition - the placement of subsequent images over earlier ones - has been successfully applied in temporal sequencing of rock art in places like Arnhem Land and the Kimberley region (Chaloupka 1984, 1992; Lewis 1988; Walsh 1994). The second is that a small percentage of engravings appear to have been retouched (Virili 1977: 442). Retouching may be a cultural trait associated with the particular group that originally produced the images, such as the reinvigoration of Dreaming figures in the Wandjina art of the Kimberley and observed in the Victoria River district of the Northern Territory (Lewis and Rose 1988). However, observation of the Dampier Archipelago examples suggests that the retouching is much more recent than the original creation of the images.

Previous attempts to provide a chronology to the rock art of the region have used comparison of the relative contrast of rock and petroglyph surface, used in combination with stylistic and subject indicators (Lorblanchet 1983, 1992). For the Dampier Archipelago, the numerical density and widespread occurrence of the petroglyphs counters any bias that micro environmental situation may have in the rates of repatination. The most distinctive division in the rock art is that between the deeply weathered and fully patinated forms that include terrestrial subjects (macropods and emus) and the less patinated marine fauna (fish and marine mammals).

\section{TOWARDS A SEQUENCE}

In an early paper on rock art relevant to the Dampier Archipelago, McCarthy postulated an antiquity of several thousand years for the petroglyphs of Depuch Island based on superimposition (McCarthy 1961: 145). Depuch Island is a near coastal island some $95 \mathrm{~km}$ east of the Dampier Archipelago. McCarthy described the earliest phase as comprising outline figures (humans and fauna), while later phases (at least three) comprised internal design or intaglios (fully engraved) with the density of pecking varying.

Virili (1977) touched on the possibly of a Pleistocene antiquity to the Dampier Archipelago petroglyphs. However, it was not until Lorblanchet carried out field work in the mid 1970s that any attempt was made to provide a chronology for the Dampier Archipelago rock art. Focusing on the petroglyphs within a single valley toward the southern end of Dampier Island, Lorblanchet identified three artistic periods, which he refined to four in a later paper (Lorblanchet 1983: 181, 1992: 47). In summary, these are:

Period 1A. Comprises fully patinated ghost-like human figures, human figures with exaggerated penises, profile humans, macropods and geometric elements (cupules, circles, concentric circles, ovals and lines);

Period 1B. Patinated turtles with eggs, large 
grooved outline macropods, other animal and human figures, geometric elements (mazes of lines, dumbbell-like, bi-lobed/liver?);

Period 2A. Large human and macropod figures including zoomorphs, reptiles and other animals, fish, geometric elements (bi-lobed/liver?);

Period 2B. Fresh looking petroglyphs, comprising human figures, including one particular variety with oversized hands and feet.

Lorblanchet's sequence is in fact a coalescence of art styles and engraving techniques, and because of the limitations of the area surveyed it does not include many diagnostic motifs found throughout the Dampier Archipelago.

Investigating sites throughout the archipelago, thus increasing the sample size both spatially and numerically, it becomes apparent that the art phases that do occur are not quite as Lorblanchet envisaged, with several earlier phases and an expanded range of subject styles within each petroglyph tradition. Having examined many more rock art locations and looked at tens of thousands of images it is now possible to better define the art sequence and to determine that these traditions operated for varying periods of time. However, interpreting the temporal sequencing is still reliant on the same fundamentals of patina, form and style that Lorblanchet himself applied.

Diversity in subject and form of the Dampier Archipelago petroglyphs is one of the characterising features of its art corpus. Grouping motifs into subject classes, although facilitating certain types of analysis, tends to obscure some temporal trends and particular art phases. Some of the general trends are:

- $\quad$ shift from deeply engraved outline form to shallow pecked/bruised solid (intaglio) form;

- $\quad$ shift from elaborate and detailed to simple and stylised in subject and form; and

- $\quad$ transition from terrestrial to marine faunal subject dominance.

The introduction of marine fauna as subjects in the rock art of the Dampier Archipelago is a key marker in the sequence proposed here. It is on the near coastal islands of Dampier and Dolphin Island that the most heavily weathered, repatinated (earliest) examples appear. However, not all islands have been investigated to the same extent, and further corroboration is needed to ensure this observation is not simply a factor of sample size. Indeed, the depictions of marine fauna, particularly fish, are more spatially restricted than other motif subjects of similar patina. It is quite feasible that there is an early phase to the marine subjects, connected with a time prior to the arrival of the ocean. Certainly the existence of trumpet shell (Syrinx aruanus) remains dated to the Pleistocene attests to the fact that coastal contact did exist at that time (Lorblanchet 1983).

It is thus possible to discern a temporal sequence of grouped motif types based primarily on the degree of repatination and the weathered condition of the surfaces on which images are produced, coupled with technique and style of production. The characteristics of each phase will now be described.

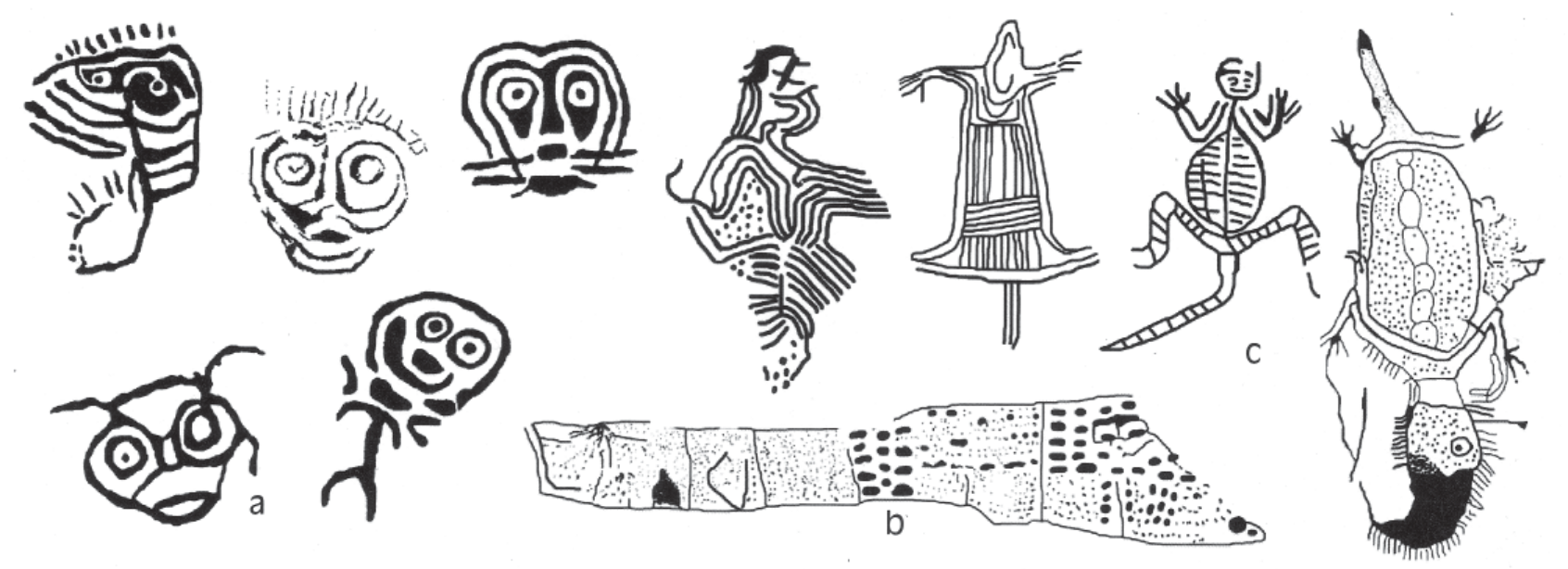

FIGURE 3 Line drawing examples of archaic face images, elaborate geometric designs and of zoomorphs incorporating elements of the other two. 


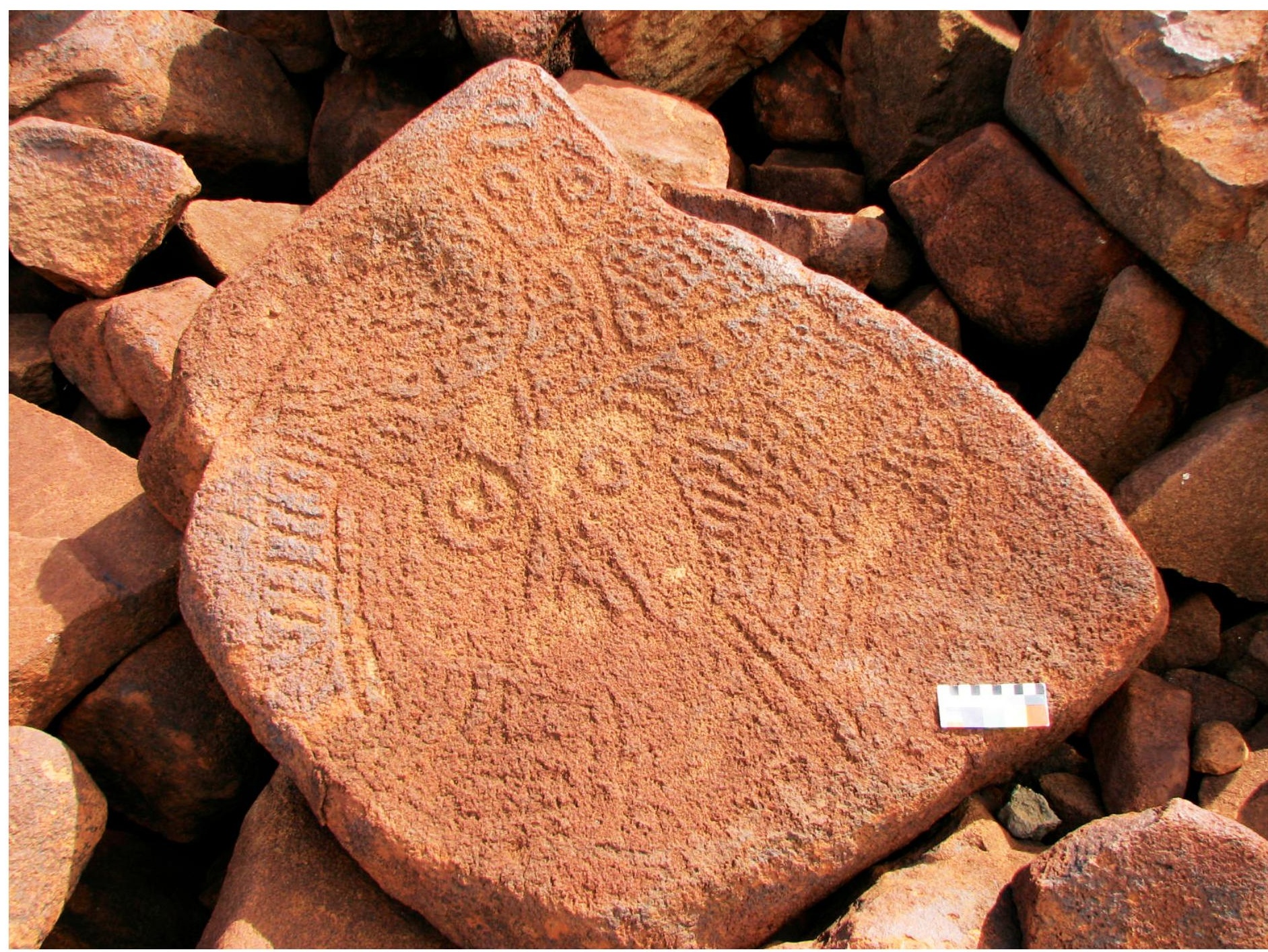

FIGURE $4 \quad$ Design created by relief-carving to form a face like image.

\section{PHASE 1}

The earliest surviving art (Phase 1) is the group comprising 'archaic faces', elaborate geometric configurations and anthropomorphs that include design elements of the other two (Figure 3).

Much has been written about the 'archaic-face' motif that is found on Dampier Island, in the inland Pilbara and as far eastward as the Cleland Hills, 1,500 km away (Edwards 1968; Dix 1977; Veth et al. 1994; McDonald 2005). The most salient features of these images are the concentric circle pattern for eyes and that the images are formed by the rock that remains rather than what is removed (Figure 4). A variant of this art tradition is also found in the Victoria River District of the Northern Territory, some $1,700 \mathrm{~km}$ to the north-east (Lewis and McClausland 1987). Several 'archaic face' images are also reported at a site on the Mulligan River, northwest of Birdsville, Queensland (Iain Davidson pers. comm. 2007). The widespread distribution of these distinctly complex, heavily weathered images may pertain to a period of low population density and high mobility, a situation that the hyper-aridity of the LGM may have necessitated some 22,000-18,000 years ago (see Smith 1992). The extreme weathering and degree of repatination of these images as they are found on Dampier Island also attest to a likely great antiquity for this particular art tradition and supports the LGM connection.

Along with the 'archaic face' motifs there are complex geometric images (mazes) that utilise a number of elements, including fitting the full available canvas of the rock face (Figures $3 a, b)$. In a few cases these two classes of images appear on the same rock panel. The complex geometric designs comprise linear, circular and bar/dot elements, which may be framed by the rock face edge and/or with an enclosing linear component. Related to these artistic elements are the relatively large $(30-200 \mathrm{~cm})$ anthropomorphic and therianthropic figures, which also utilise geometric designs (Figure 3c).

Contemporary with them, or slightly later, is the appearance of human figures with disarticulated, blob-like heads and stylised, long-legged birds and 


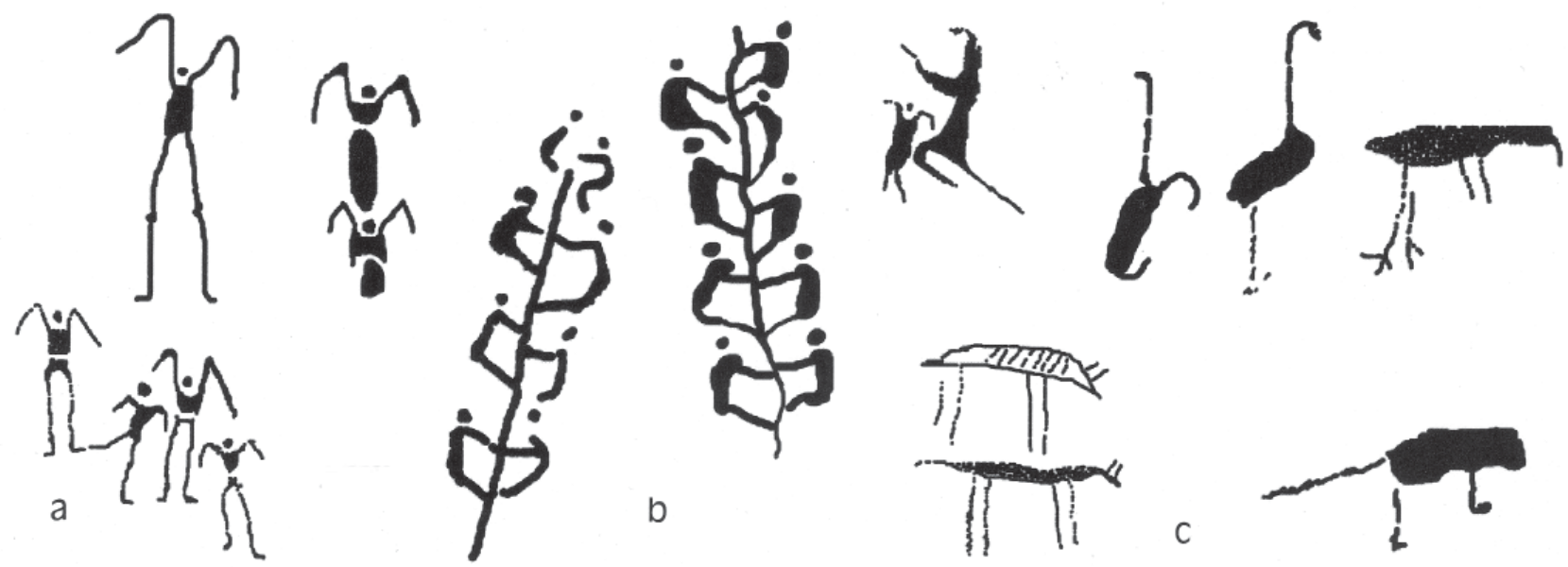

FIGURE $5 \quad$ Line drawing examples of other image forms associated with the earlier artistic phase; dot head human forms and small stylised fauna.

quadrupeds. The human figures exhibit a range of stylised body forms, but all have in common a disarticulated 'dot-head'. They occur individually and as groups (Figure 5a). These groups are often dynamic scenes or depictions of association, linked by spatial juxtaposition or attached to a line. In some examples, individuals appear to be holding 'axe-like' objects or implements similar in appearance to a 'No 7 boomerang' (Figure 6). There is a distinct form side profile, with bent leg and arm. These depictions are most often linked with a line or other linear design, as if the figures are holding or supported by the line (Figure 7). The most famous example is the group giving the name to the 'climbing-men panel' $^{\prime}$ (Figures $5 \mathrm{~b}$ and 8). It is unfortunate that this particular motif has been recently interpreted as 'men climbing up the rigging of a sailing ship' (see Barnett 2006), given that other more plausible interpretations have been advocated for many years

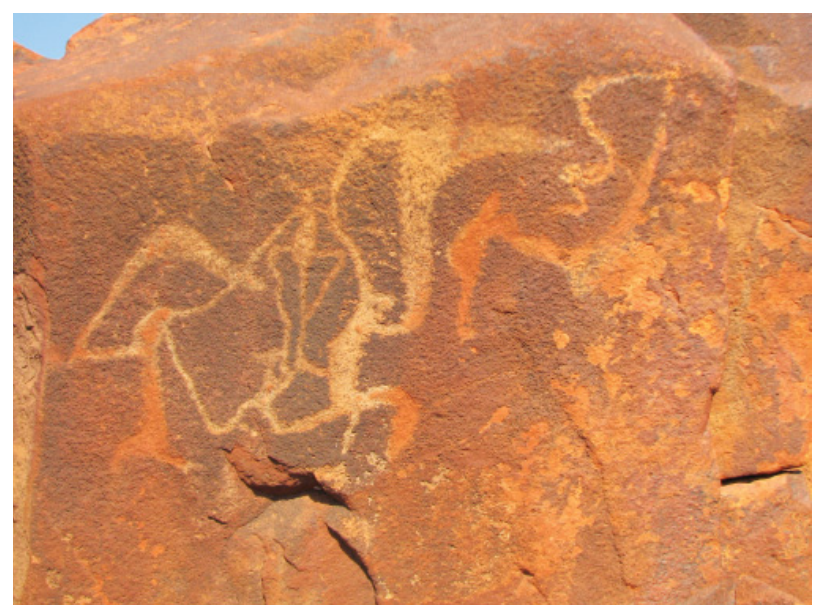

(e.g. Sales 1992). If this truly were the case, it would predate the development of sea going masted ships by tens of millennia. The real relevance here is that all the early art phase components are together on the 'climbing-men panel', lending support to the contention that all are in close temporal association.

Stylistically aligned to the 'dot-head' human figures are simplistic faunal depictions that, like the human form, have proportionately long, thin limbs (Figure 5c, 8). These limbs often end with an upward sweep, possibly indicative of hands, feet and paws. A second feature of these stylised human and fauna depictions is that they are not as deeply pecked (size and density) as the other, more elaborately designed petroglyphs of this period. Like the dot-head human figures, the size of individual images within this fauna class of motif is generally smaller $(<15 \mathrm{~cm})$ than those of the other petroglyphs within this Phase 1 art corpus.

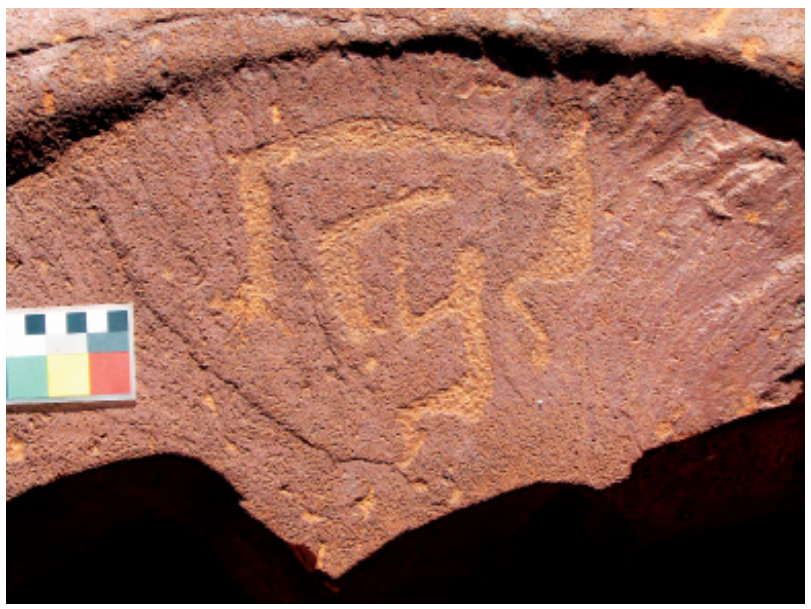

FIGURES $6 \quad$ Human figures holding 'axe-like' objects or implements similar in appearance to a 'No 7 boomerang'. 


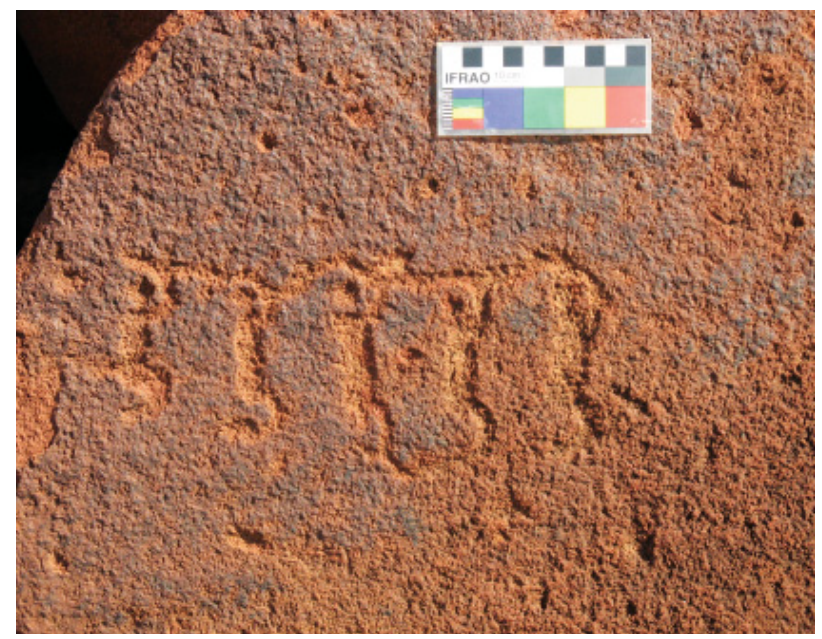

FIGURE 7

Side profile 'hanging men' of the dothead form.

\section{PHASE 2}

Phase 2 is characterised by the production of large (1.5-2.5 m), deeply engraved, outline form terrestrial fauna - emu and macropod depictions (and to a lesser extent pythons), and anthropomorphic figures (Figure 9). A feature of this phase is the placement of images on prominent, clearly visible, often vertical rock surfaces. It is quite feasible that this shift in artistic representation signifies a discontinuity in the production of petroglyphs within this area. Simple, elemental geometric designs and deeply pecked, relatively large emu and macropod tracks are also associated with this period based on patination. At this time the Burrup Ranges would have stood up from a vast open savannah plain. Within the later part of this period there is a trend to a wider range of fauna depicted, including thylacines and goannas, and diversity in

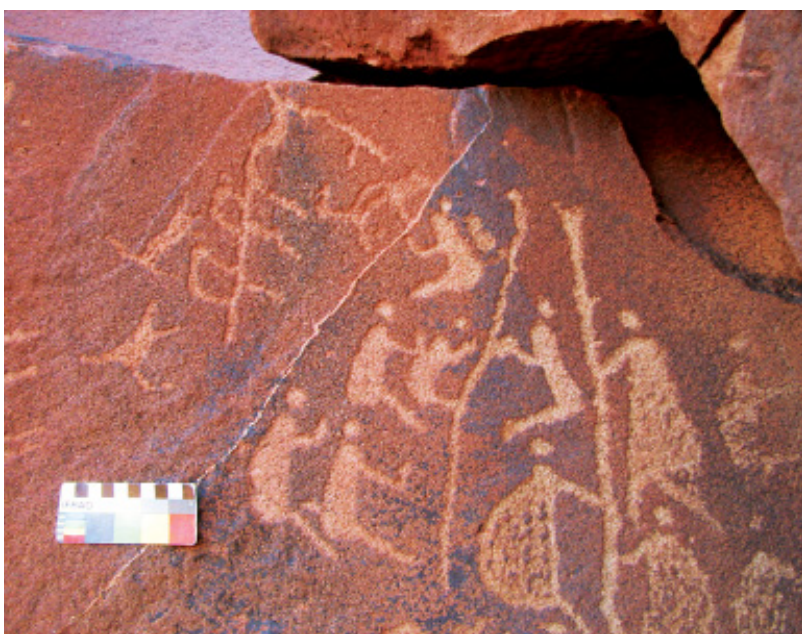

FIGURE 8

Examples of the 'climbing men' form and of the archaic phase quadrupeds.

the way human figures are portrayed.

A specific artistic convention with the macropod depictions seems to be the inclusion of a bar/line across the base of the tail (sometimes also at neck), and with the mouth represented by a slit and eyes depicted by dots. Like their faunal counterparts, a pair of eyes depicted as dots can be a feature of the outline anthropomorphic images. Many of these images have been pecked then abraded within the outline groove forming the image. Lorblanchet (1983) comments on this characteristic, ascribing it to his second art phase (Period 2A). At this stage there is uncertainty as to the degree and frequency of the reworking within the engraved groove, although it may be an artistic convention of the original production rather than subsequent repecking of the image.
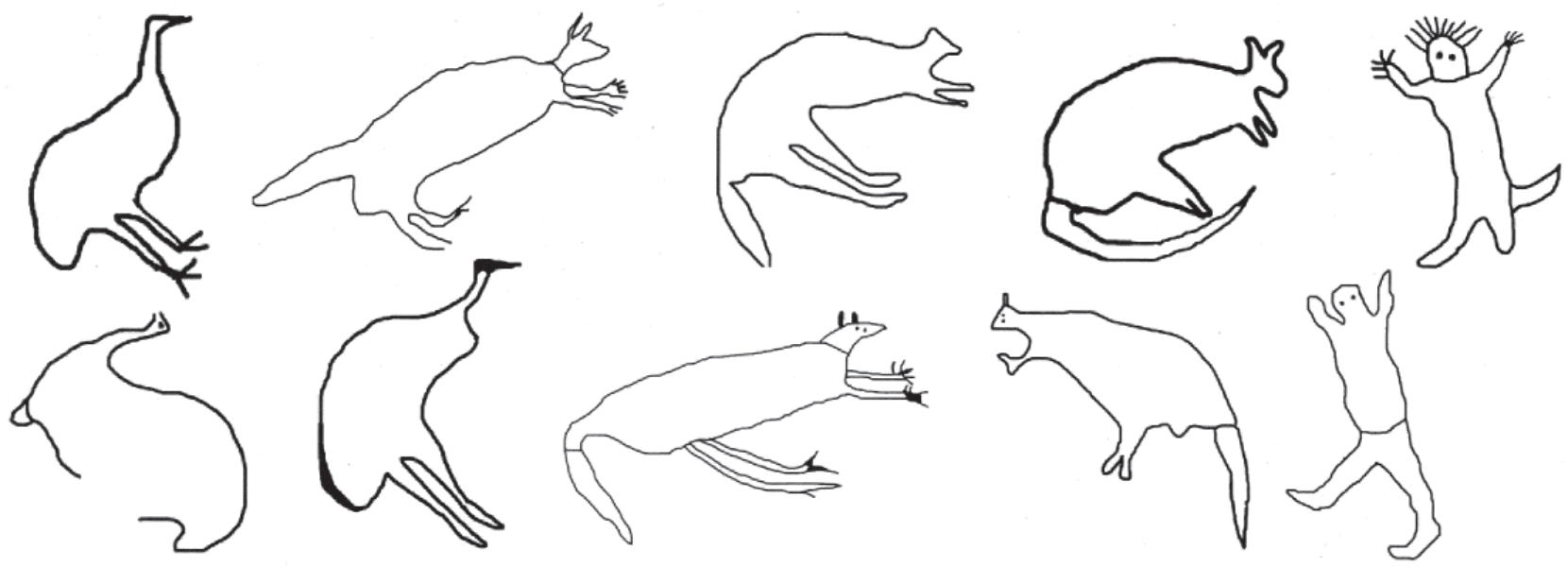

FIGURE $9 \quad$ Line drawing examples showing large outline forms depicting macropods and emus. 


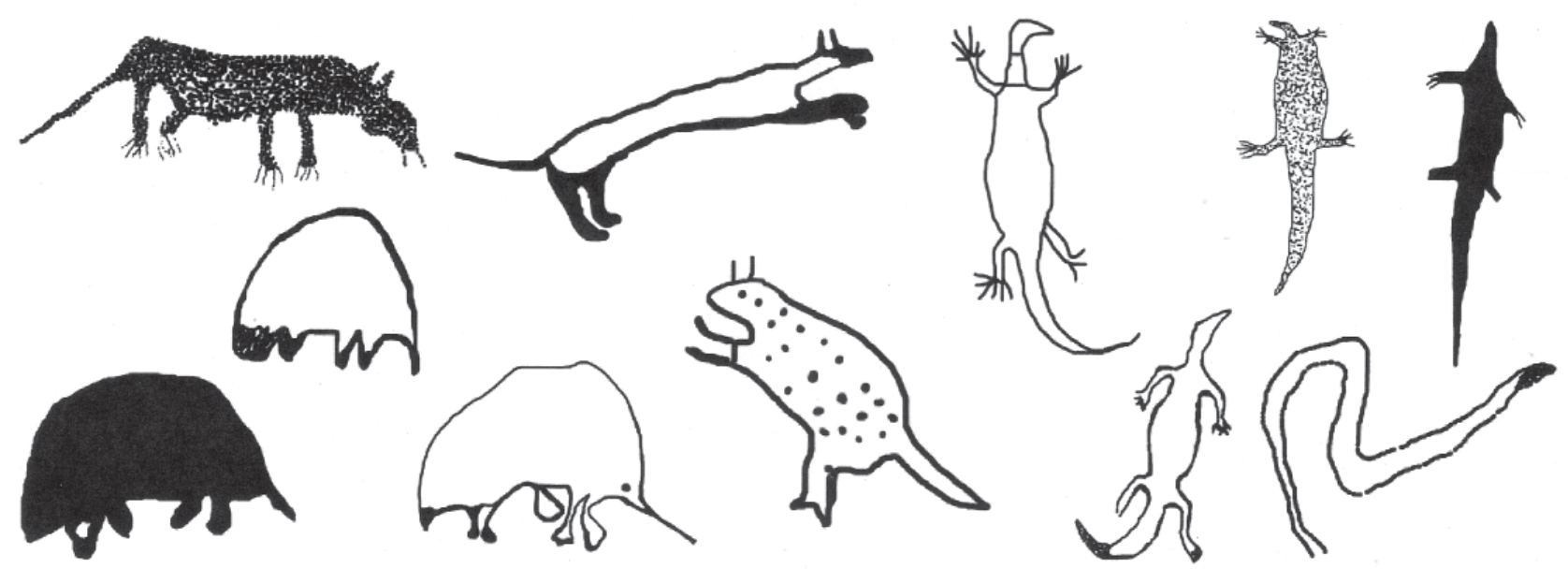

FIGURE 10 Line drawing examples of faunal depictions; including quadrupeds, echidna, lizards and possible quoll.

\section{PHASE 3}

Phase 3 rock art production expands on the range of faunal depictions, although there is an apparent decline in emu images. This burgeoning of bird and animal subjects includes turkeys (bustard), ibis and birds more associated with well-watered, rather than dry, open-plains country. Fauna include quadrupeds (thylacine, quolls), goannas, snakes and echidna (Figure 10). There are also a few images of what is, undoubtedly, long-neck tortoise, a freshwater species (Figure 11a). A diagnostic feature of this art phase is that the images are reduced in size, although often depicted life-size rather than the exaggerated form characteristic of the previous artistic tradition. There is also an increased array of styles depicting human forms. Art of this phase has a greater size range, images are not as deeply engraved as in the preceding period and placement in the landscape becomes more varied. The form of the image also is more diverse, with outline, solid and internal design being evident. Repeated motifs of particular style anthropomorphs are also a feature in the art of this phase.

Forms of the images associated with this period also suggest a transition from the deep outline groove to a slightly shallower pecking with infill or as intaglio (completely engraved silhouette). In the case of the thylacine and quoll, the infill is integral to the diagnostic features of the subject (however, see Mulvaney 2009). Human figures, anthropomorphs, and possible therianthropomorphs, of this period also reflect this preference for the solid form. In addition, grouped figures now occur, rather than individual motifs on separate rock faces. These large paired and grouped anthropomorph forms are

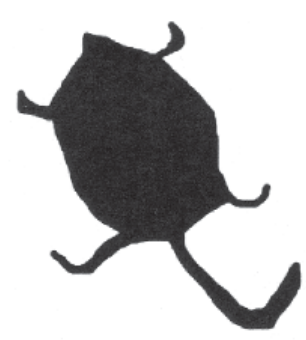

a

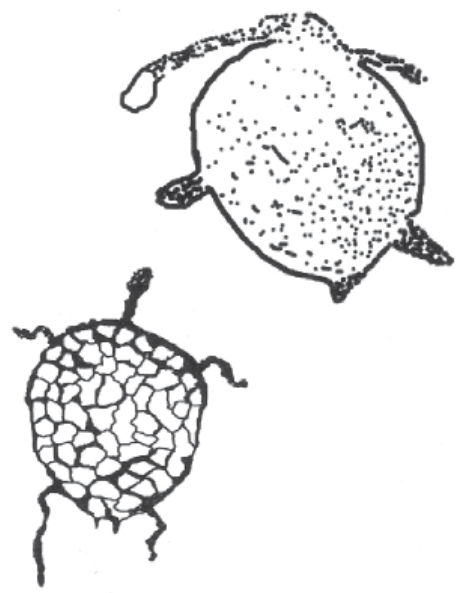

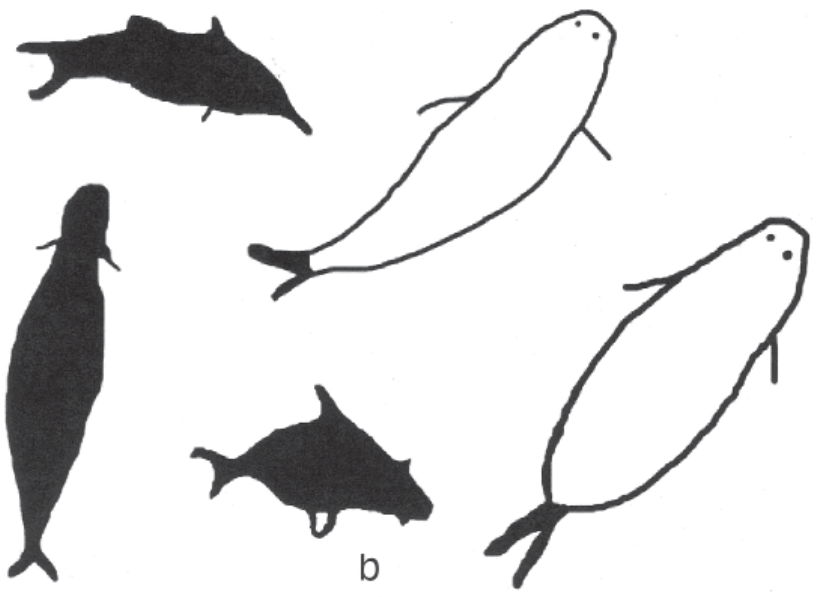

FIGURE $11 \quad$ Line drawing examples of long-neck tortoise and early examples of fish. 


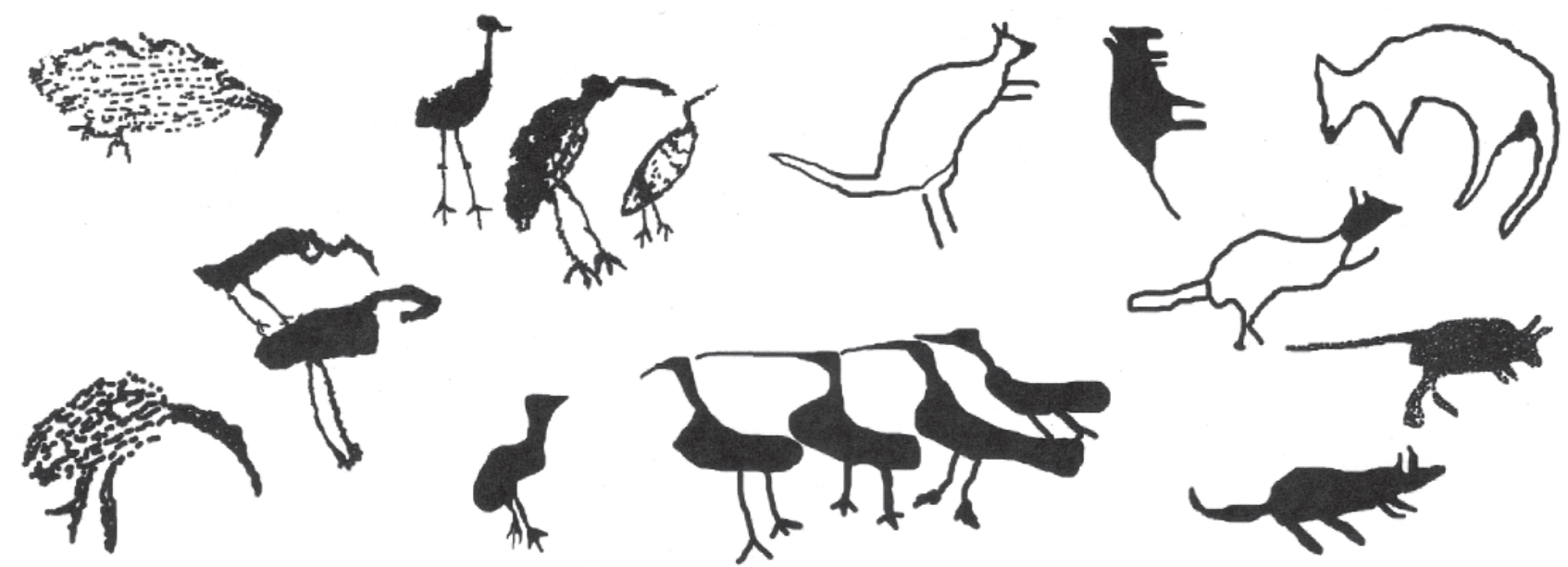

FIGURE 12 Line drawing examples of stylised forms of bird and macropod depictions.

often placed on prominent panels and conspicuous locations. In addition to a general reduction in image size, they are also more variable in size compared to the images of Phase 2. The proportions of the depictions correspond less with anatomy and are more stylised, with increased variation in form (Figure 12). It is possible that this aspect may indicate that a greater number of individuals were involved in producing the petroglyphs. Depictions of marsupials and avifauna tracks also follow this trend and are smaller and more stylised. There is also the first appearance of the human foot and possibly hands, and tracks of other animals. Other new and specific styles appear, most evident in the development of the macropod depictions and human forms.

\section{PHASE 4}

Phase 4 is evidently associated with the formation of the Dampier Archipelago as a consequence of sea-level rise. This phase sees the dominance of marine fish and mammals in the faunal repertoire of the petroglyphs. Of these, turtles are clearly important in numerical representation, stylistic variation and geographic placement. It is also likely that small clusters of pecked pits (cupule like), which may appear in association with turtles, are representations of the eggs of this creature (Figures 13, 14). Depictions of birds also shift from predominantly terrestrial to aquatic species. There is also a corresponding change in the way human images are depicted. Group scenes and dynamic representation appear in the art of this phase, with individual motif size relatively small $(10-25 \mathrm{~cm})$ in
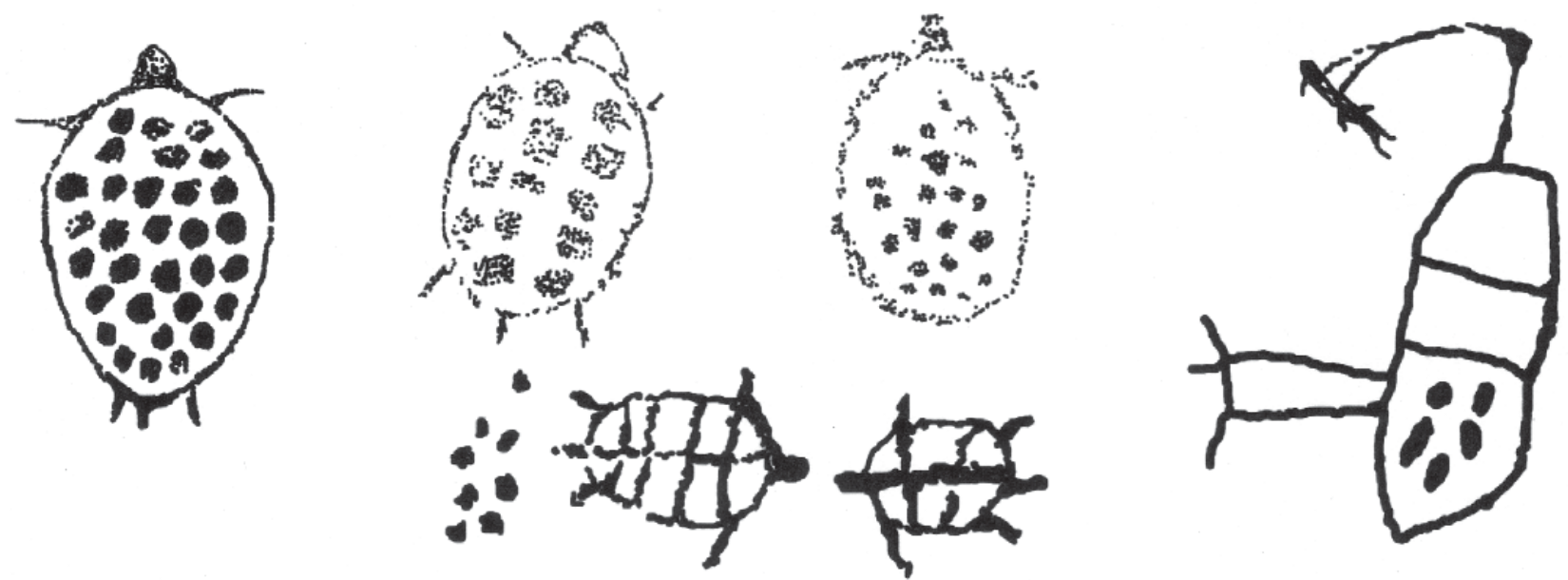

FIGURE 13 Line drawing examples of turtles and a bird with artistic element which may well represent eggs. 
comparison to human depictions of the preceding art tradition.

Images are in outline form, and may or may not have internal designs, or be fully pecked. The images of both turtles and fish are relatively deeply pecked, although not to the extent of the large outline images of terrestrial fauna in the earlier phases. In the case of the turtles the patterning denotes the carapace or shell. Fish are mostly depicted in profile although some rotation (twisted perspective) may be employed (Figure 15). Marine mammals can either be shown from the side or top view, and some have paired eyes (like the faunal depictions of Phase 2). In addition to dugong, particular species can be identified at least to the degree that they are pelagic rather than reef and inshore species.

The trend seen in marine subjects toward anatomically defining features rather than generic depictions is repeated in images of avifauna. Lightly pecked, abraded and pounded intaglio birds depicting species such as pelican, ibis, sandpiper and diver-duck have been recorded on Dampier Island and other islands (Figure 16). However, terrestrial fauna do not appear to be depicted in corresponding detail for the identification of species, although snakes, goanna and echidna are depicted alongside generic macropods.

There are also trends in the geometric component and in the tracks, from the large deeply pecked bird and macropod tracks of the earlier periods to more varied and stylised shallow pecked, bruised tracks. In the case of macropods there are examples of the fore and hind prints and that of the tail (resting position). Four-toe (wader birds) rather than just the three-toe (emu) track images appear in the repertoire, and some of the bird tracks are depicted as outlines with internal linear patterning. It is within this phase of rock art production that solid human feet (and occasional hands) appear in the art corpus.

During this period there is also a change in the manner of human depiction, with the reemployment of group arrangements. This inclusion of numbers of human figures, in association rather than static images of single figures, utilised dynamic poses and group activities. It is also during this phase that images clearly depicting economic activities occur. These include spear and possible line fishing, spearing of macropods and netting/ corralling of dugong (Figure 17). Alternatively, it has been observed that these features are more like attachment lines showing association rather than spears and may be recounting Dreaming stories or 'hunting magic' rather than actual events (Gunn pers. comm. 2006). There is a greater range of size of images within subject classes during this period, with images as small as $10 \mathrm{~cm}$ and as large as $2 \mathrm{~m}$.
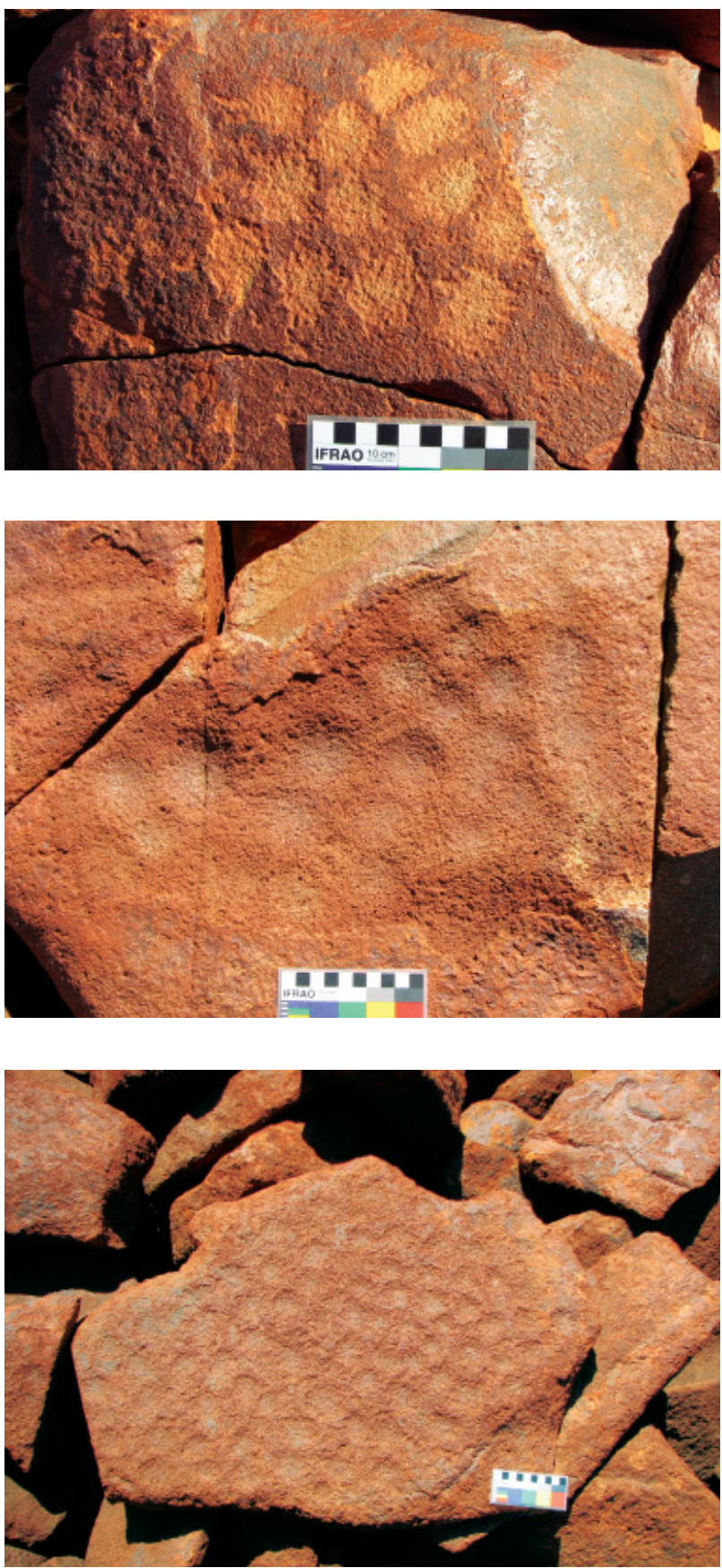

FIGURES 14 A repeated motif comprising a cluster of pecked discoid or cupules.

\section{PHASE 5}

At least one later marine art period (Phase 5) is evident within the Dampier Archipelago. This comprises shifts in the way marine images are portrayed, and may well include the introduction of incised (scratched) images. However, due to the shallow nature of this technique, producing a low contrast threshold and minimal profile, it is possible that any earlier cases are no longer visible or have not been detected.

Variation in the technique, style and subject range of the marine fauna in the rock art repertoire 


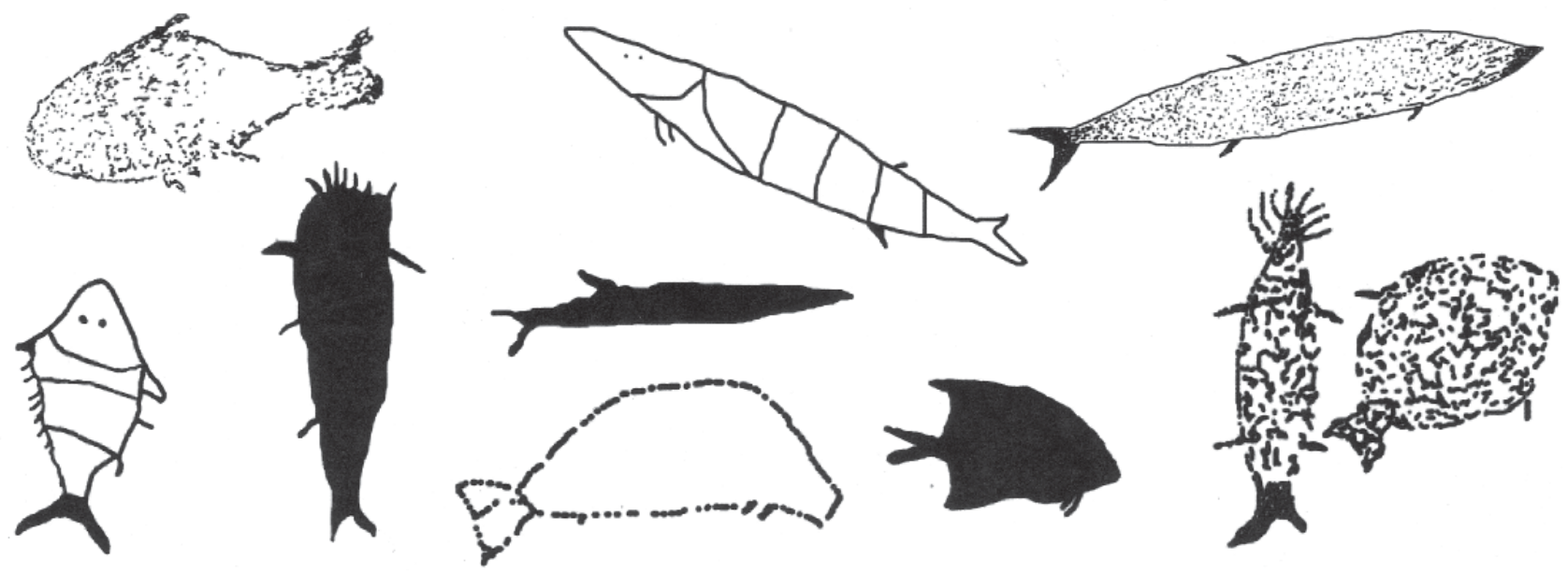

FIGURE $15 \quad$ Line drawing examples of the range of depictions of marine fish.

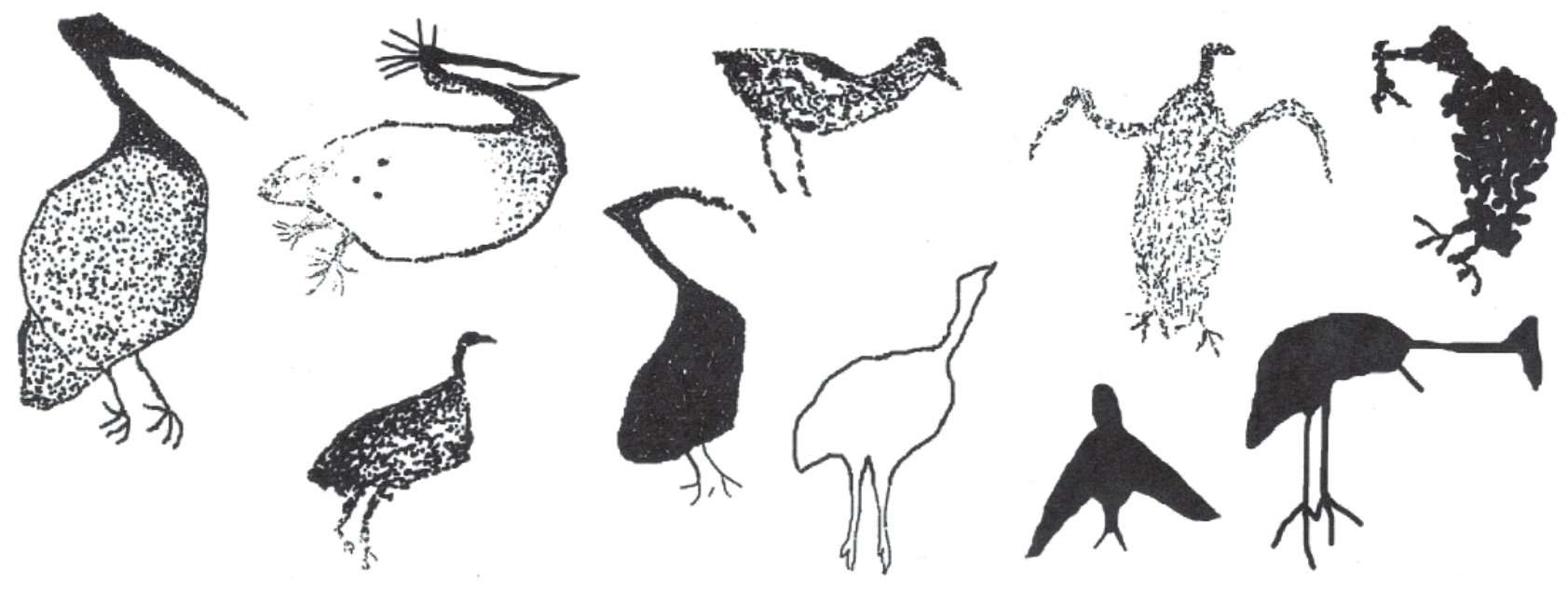

FIGURE 16 Line drawing examples of identifiable bird depictions of pelican, bush turkey, ibis, stork and waders.

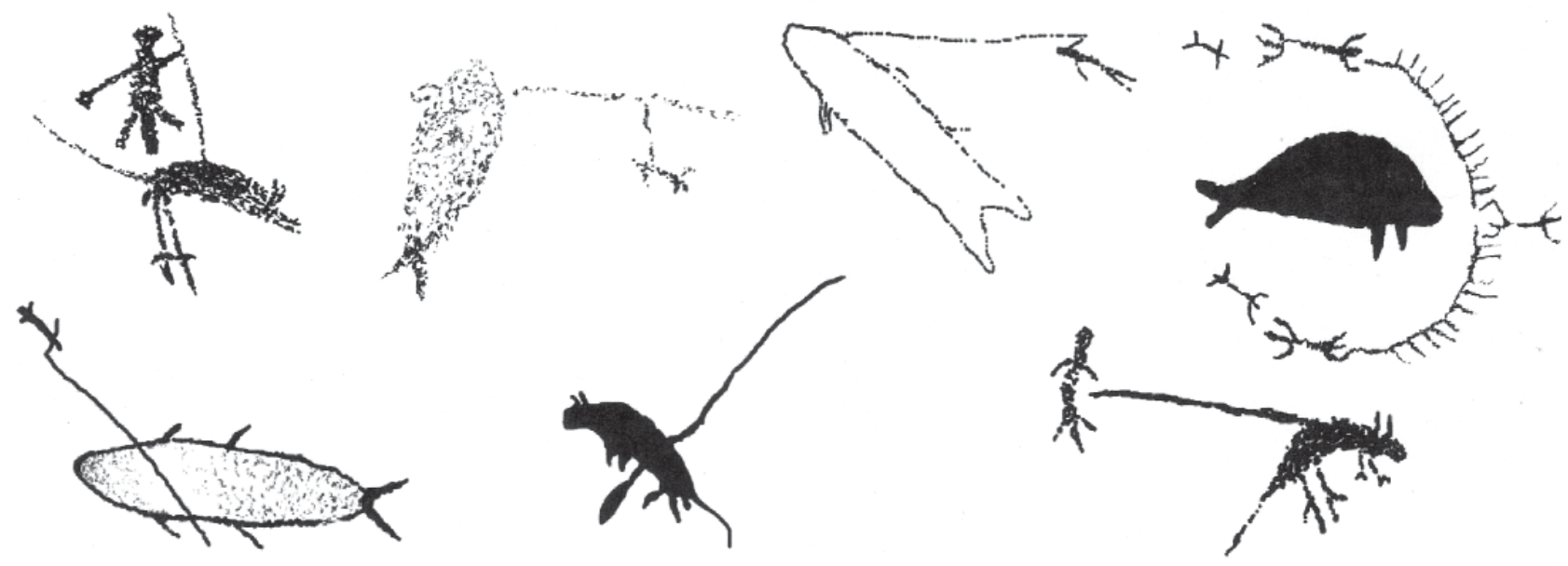

FIGURE $17 \quad$ Line drawing examples showing hunting and trapping activities. 

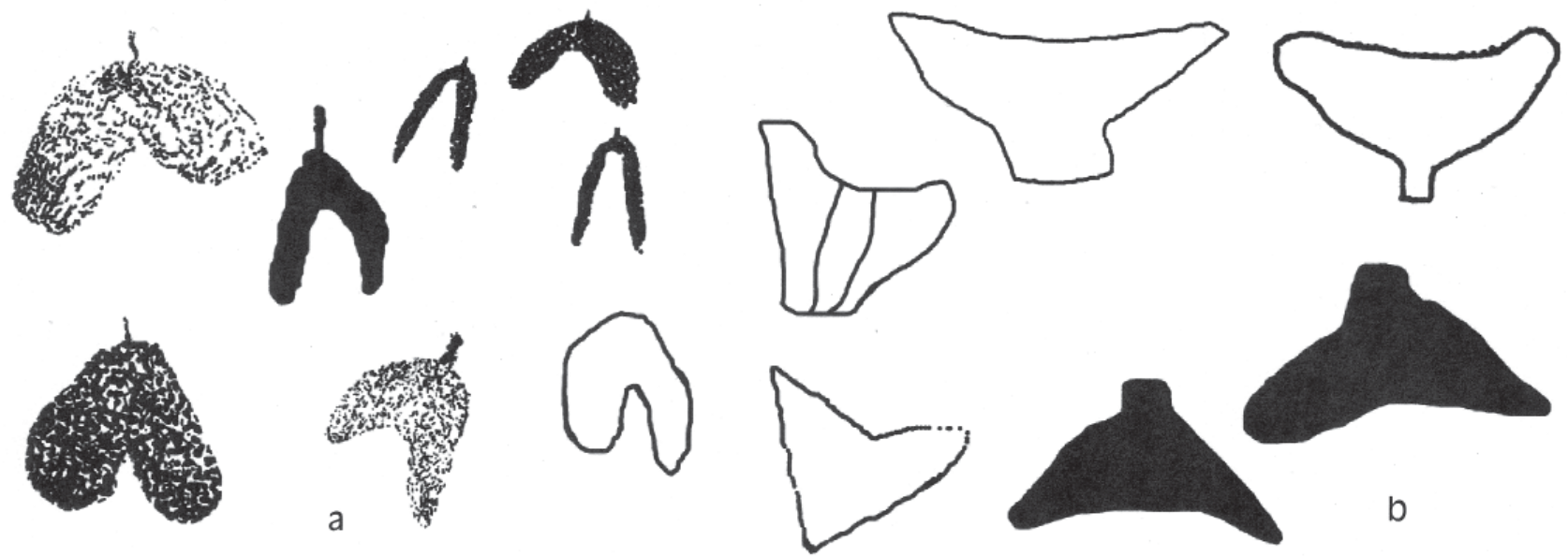

FIGURE 19 Line drawing examples of simple designs identified as stingray and shark livers, and tail of dugong or whale.

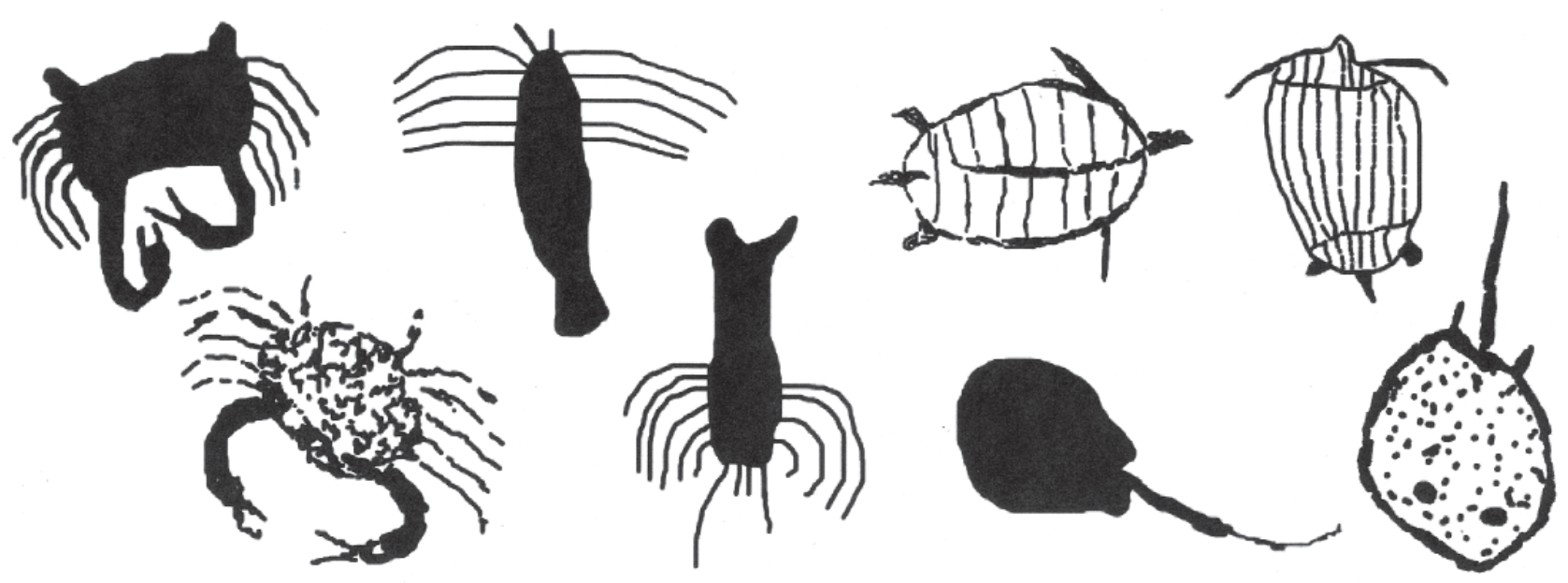

FIGURE $18 \quad$ Line drawing examples of marine subjects; including crab, crayfish, turtle and stingray.
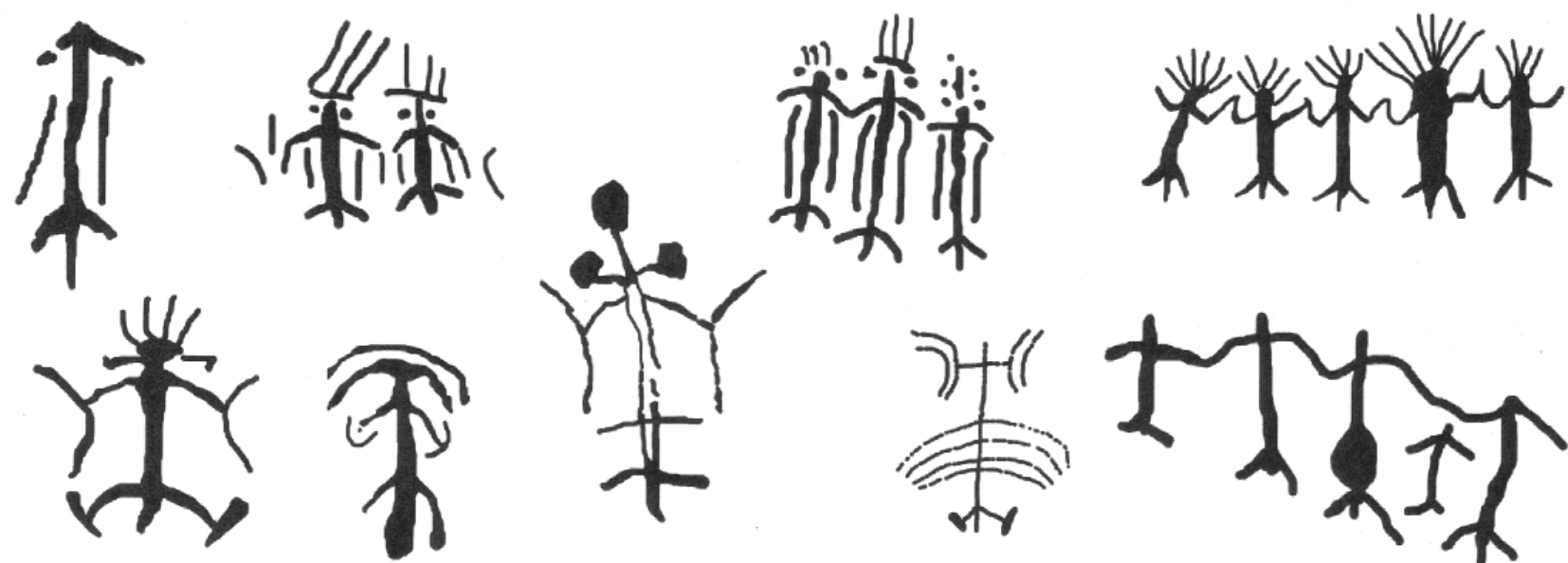

FIGURE 20

Line drawing examples of a range of human figures with associated objects and line group arrangement. 

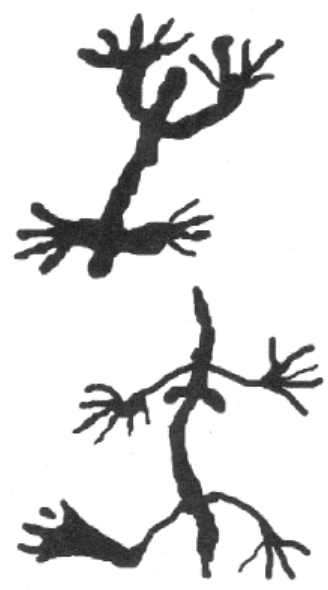
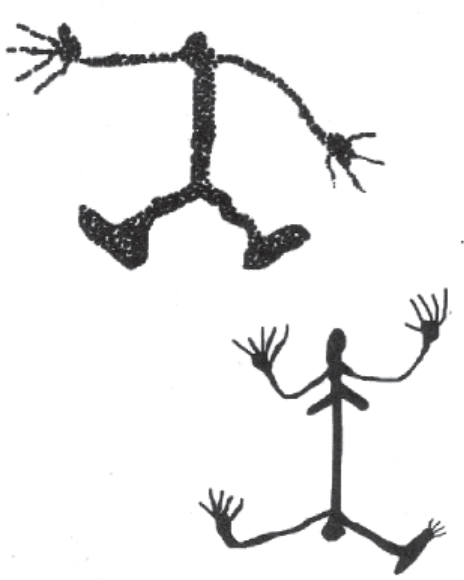
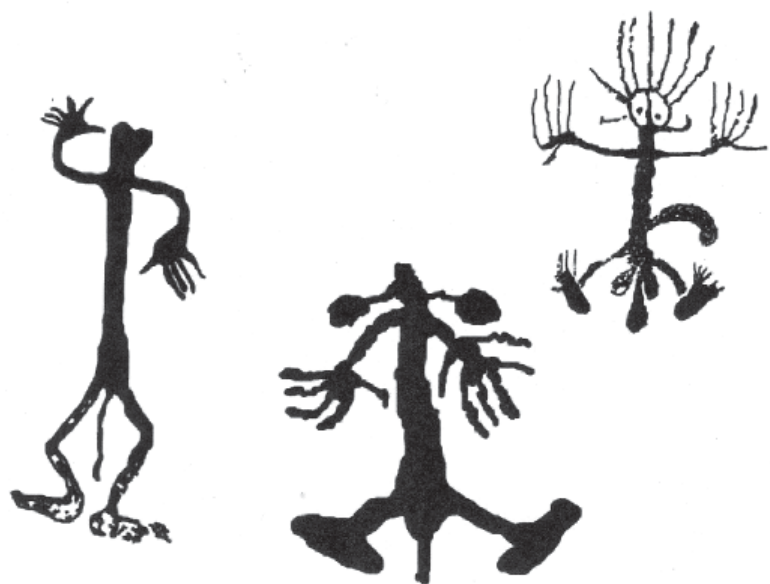

FIGURE 21

Line drawing examples of human figures with distinctive over sized hands and feet.

increases from the 'early examples' of Phase 4 to forms that included outline as well as intaglio produced by shallow pecking or simple bruising of the rock surface. There is an accompanying expansion in the range of fish species depicted. The spatial distribution of these motifs is restricted; they primarily occur within the coastal strip on the larger near coastal islands and on the outer islands. Other marine species also appear in the rock art repertoire, including stingrays, whales, crabs and, to a much lesser extent, crayfish (Figure 18).

The increase in marine subject depictions is accompanied by the appearance of two very distinctive and commonly repeated motifs (Figure 19). One of these, a bi-lobed intaglio form with a single line appendage, is normally referred to as a 'sting-ray liver' (McCarthy 1961; Lorblanchet 1983; Vinnicombe 1987). McCarthy, having consulted local Aboriginal informants, originally reported this interpretation and to date Traditional Owners of the area have not expressed an alternative view. Certainly, there are similarities with contemporary painted art of coastal Arnhem Land and the importance of both stingray and shark livers in the culture of these people. The other motif has the shape of a whale or dugong tail. This motif is either depicted in solid form or as an outline, with rare examples of outline with internal design. Both forms were produced by simple bruising of the rock surface or by pecking marginally deeper than bruising.

Human figures seem to be depicted in two different ways at this time (Figure 20). One variant, and possibly the slightly earlier of the two, is simple stick figures arranged as a row, often with linked hands and feet, much like paper cut-out lines of human figures. The other variant is simple human figures; these are single or paired, and sometimes grouped, with associated embellishments that are linked to ritual paraphernalia and activities. These additions to the human form include paired arcs (boomerangs?) that may be at the end of the upper limbs or offset from the torso, paired dots adjacent to or above the head, and short lines or bars usually associated with the head. One very distinct motif of this later period is the production of human figures with exaggerated feet and hands (Figure 21). These particular anatomical features are intentionally overstated, often with toes and figures spanning out from otherwise simple stick figures.

Associated with the most recent period is a plethora of small simple intaglio birds, some larger with internal lines, a number in association with wavy-lines (possible snakes). Turtle, fish and a range of simple stick figures are also produced. All images are relatively small $(<60 \mathrm{~cm})$, although in combination they can fill adjacent panels and present a gallery of images that cover many tens of square metres. This aspect is most developed on North Gidley Island. As noted above, the images from this phase are typically very fresh in appearance and unpatinated.

\section{DISCUSSION}

For the Dampier Archipelago, such a cornucopia of rock art is partly explained by the very hardness of the rock and the resilient weathering pattern that preserves the images. The particular geomorphology of the archipelago may also account for the abundance of water, the block slopes and fractured bedrock acting as a reservoir rather than allowing water to be lost to run-off. This availability of potable water ensured people's presence within the granophyre dominated landscape. The abundance of subsistence resources, food and materials, is also part of the explanation which allowed people the flexibility of time and the balance of pursuits other than subsistence activities to produce the 
images. Spinifex resin is one other resource that is immensely valuable. This essential glue is obtainable in the form of the building material from ant nests and trails over the rocks of the Dampier Archipelago (Figure 22). It is quick and easy to collect, and is clean and readily packaged. This is in contrast to the laborious process of obtaining resin in the sand plains country covering much of Australia. As an exchange item it would have been highly desirable, as a valued resource that would have eased the burden of subsistence living.

Results from rockshelter excavations in the inland Pilbara have established human presence in the region from approximately 30,000 BP (Brown 1987; Veth 1993; Marwick 2002). On the Montebello Islands to the west of the Dampier Archipelago, there is occupation evidence from about 27,000 $\mathrm{BP}$ until they became islands as a consequence of the rising sea levels, c. 7,000 BP (Veth 1993). It is indisputable that people had reached this part of Australia by the late Pleistocene. Available data supports early occupation of the region, but debate remains as to continuity of presence and viability of a resident population during the Pleistocene arid phase. The available data comes from rockshelter sites and by no means represents the pattern of subsistence settlement in the region. Quite feasibly subsistence strategies oscillated seasonally between coastal marine exploitation and interior rangeland utilisation that the, now submerged, vast open grassland plains would have afforded. Apart from specific locations like the prominent rocky ridges and valleys that the Dampier Archipelago affords, much of the evidence of the ancient human occupation is now under the sea.

The particular geology and geomorphic processes that have formed the Dampier Archipelago are what has created the specific conditions for the long-term use and rock art preservation. During the LGM, the rugged landscaped of the islands that now form the archipelago would have been outlier hills and ranges prominent in a vast open plain. The secluded and protected rock holes and springs within the deeply incised valleys of this rock-piled landscape would have been one of the influencing factors in ensuring human presence. Even during the Pleistocene, the ecological diversity afforded by this unique landscape would allow the luxury of art production. However, even then it is likely that the petroglyphs were more than pretty pictures or graffiti; that they formed an essential element of society and culture. The requirement to reinvigorate the landscape, reestablish community ties, reconnection with the spiritual awareness of the area, possibly driving the production of rock art and maybe at times the reengraving of existing motifs.

The notion of artistic production within Australia as having great antiquity is well established (see

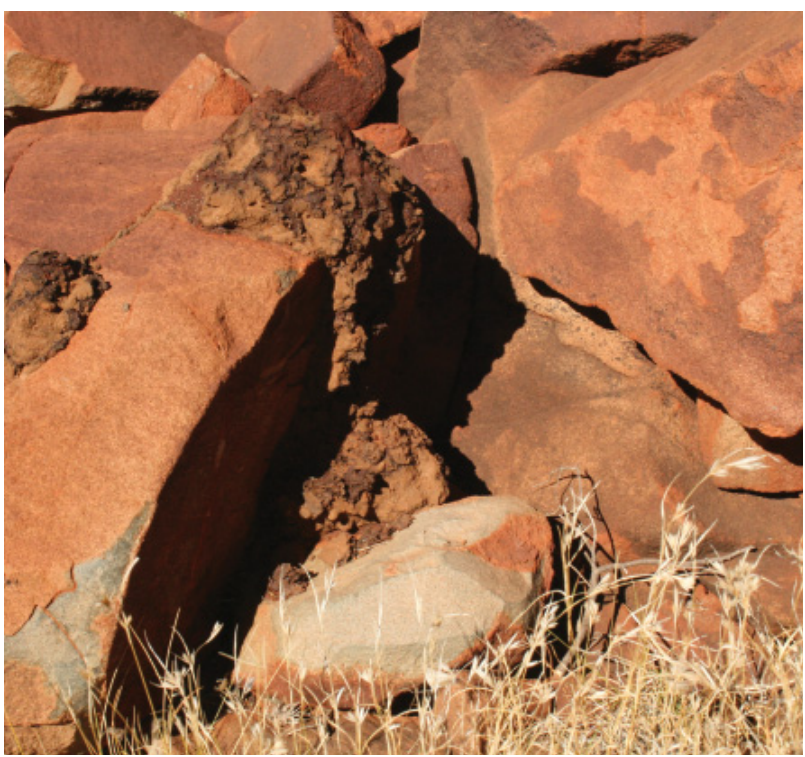

FIGURE 22

Spinifex resin used as a building material for ant nests and trails over the rocky outcrops.

Morwood 2002: 140-142). However, much of the data relates to pigment usage and not petroglyphs, the north Australian Malakunanja evidence possibly being the oldest (Roberts et al. 1990; Watchman and Jones 1998). Ochres in deposit at two Central Australian rockshelter sites, Puritjarra and Kulpi Mara, are indicative of pigment art some 30,000 years ago (see Rosenfeld and Smith 2002; Thorley 2004). This is in a region not so far from the location of the Cleland Hills 'archaic face' motifs.

Pertinent to the issue of refining dates to the rock art sequence suggested in this paper is that of the pattern within the geometric images and track motifs. There are similarities with the wide spread petroglyph group known as the 'Panaramitee' (Mountford and Edwards 1963; Edwards 1966; Maynard 1979; Flood 1997; Franklin 2004). This is a rock art tradition identified with a date range 13-18,000 to 4,000 BP (Rosenfeld et al. 1981; Dragovich 1986; Nobbs and Dorn 1993; Rosenfeld and Smith 2002; see also Flood 1997: 123-34). Based on the advent of a change in subject depiction linked to the marine transgression, the Dampier Archipelago rock art sequence, suggest Panaramitee as an art tradition is at least older than 7,000 BP.

In consideration of the general archaeological record, the extreme degree of weathering exhibited by the particular images linked to the Phase 1 art tradition are probably associated with a time of high mobility, low population density and the particular resource condition of the Burrup Ranges (what later became the Dampier Archipelago) including its guarantee of potable water. These are conditions that precede the LGM. Therefore this art tradition may relate to the initial occupation period 


\section{between 30,000 to $22,000 \mathrm{BP}$.}

The early art surviving within the Dampier Archipelago seems to relate to a period when peoples were allied and ranged over vast areas. The rock art possibly functioned as social and territorial markers, demarcating relationship through symbols of association and ownership. This seems to be the case in both the earliest and the second phase of the rock art. 'Archaic faces' and similarly depicted anthropomorphic figures are recorded from a small number of locations elsewhere in the Pilbara. Large outline emu and macropod depictions similar to those of Phase 2 are also found within the Chichester and Hamersley Ranges, and often appear to be the earliest of the rock art at the locations they occur (see also McCarthy 1961; Wright 1968). Only in the more recent periods, certainly within the last few thousand years, is there any regionally distinct pattern in the rock art, both painted and engraved. This spatial diversity strongly correlates to the identified socio-linguistic groups associated with the Pilbara.

Rather than abandonment per se, the rock art of the Dampier Archipelago supports the notion of a low intensity, opportunistic human presence throughout the period following the LGM. What the cultural connection of these people was and how far their territorial range may have been is less certain. However, the link between the 'archaic faces' of the Dampier Archipelago and inland to the Cleland Hills cannot be discounted. Similarly, there are likely cultural if not also social links between the Dampier Archipelago and the Hamersley Plateau, as evidenced with the depictions of avifauna and macropods associated with the Phase 2 period found on Dampier Island.

Within the earlier rock art of Phase 2 is the possibility of the repecking/marking of pre-existing petroglyphs. It is likely that this cultural marker pertains to a period of reduced population and intermittent occupation, patterning opportunistic forays to the location when conditions presented. Re-marking of petroglyphs reflects individual or group behaviour, perhaps functioning as a re-acknowledgement of the ancestor and/or Dreaming. Certainly the archaeological record of the Pilbara does have gaps that may be due to abandonment of areas or at least low population presence during the worst of the LGM and extending to about 13,000 BP (Marwick 2002; Veth 2005; however, see Thorley 2004; Smith et al. 2008).

Mobility brought on by the advancing coastline and strategic potable water availability, guaranteed people with knowledge of marine fauna would visit the Burrup Ranges prior to the actual arrival of the sea. This may well account for the number of marine fauna depictions that are of a style and patina that places them as earlier than the development of the specific coastal islands cultural tradition that is evident both in the rock art after 7,000 BP and the appearance of shell middens.

Apart from the Skew Valley dates associated with buried petroglyphs within a shell midden, there is a clear division in the character (both style and state of weathering) of the Dampier Archipelago petroglyphs that seems to correlate with the Holocene marine transgression. These rising sea levels keyed to the changing climate following the LGM that culminated with the establishment of the present coastline some 6,000 to 7,000 years ago (Mulvaney and Kamminga 1999: 120). There is also a geo-topographical preferencing in this faunal dichotomy that Lorblanchet recognised as reflecting the economic adjustment associated with this ecological shift (Lorblanchet 1983: 181). He characterised this division as the "art of the kangaroo hunters", and the "art of the shellfish gatherers"' (Lorblanchet 1992: 46).

The Skew Valley excavation also revealed several other aspects pertaining to the subsistence utilisation of the location (Lorblanchet and Jones 1979). A number of changes in aspects of the archaeological record occured around 4,000 BP. The shift in consumption of shellfish species from Terebralia to Anadara, and the appearance of particular stone artefact forms, such as backed blades and tula adzes, are the main indicators of change within the Dampier Archipelago. It is most likely therefore that Phase 5 of the rock art began 4,000 BP \pm 500 .

Phase 2 art, associated with the large outline renditions of avifauna and macropods, is widespread and often positioned on prominent rock surfaces. Anthropomorphic motifs of this period are more restricted in their placement than other subject categories and could well reflect the development of mythological association to places within the Burrup Ranges. Certainly in the later rock art phases there is the indication of a distinction between public art and more restricted images, as indicated by their specific placement (visibility) and association to features like the middens and grinding stones. It is also evident from the Gum Tree Valley study that locational preferences operated through time, with the focus of the petroglyphs modified with the appearance of the midden (Lorblanchet 1992: 43).

An important feature of the recent period of petroglyph production (Phase 5) is the appearance of human figures depicted with ritual accoutrements that have their parallels in today's Aboriginal society. There are a number of other indicators to ritual practices and cultural associations within the rock art of the last 4,000 years or so, not least the link to thalu sites, places where species increase rituals are performed (Withnell 1901; Daniel 1990; Mulvaney 2009). Additional changes to rock art production are 


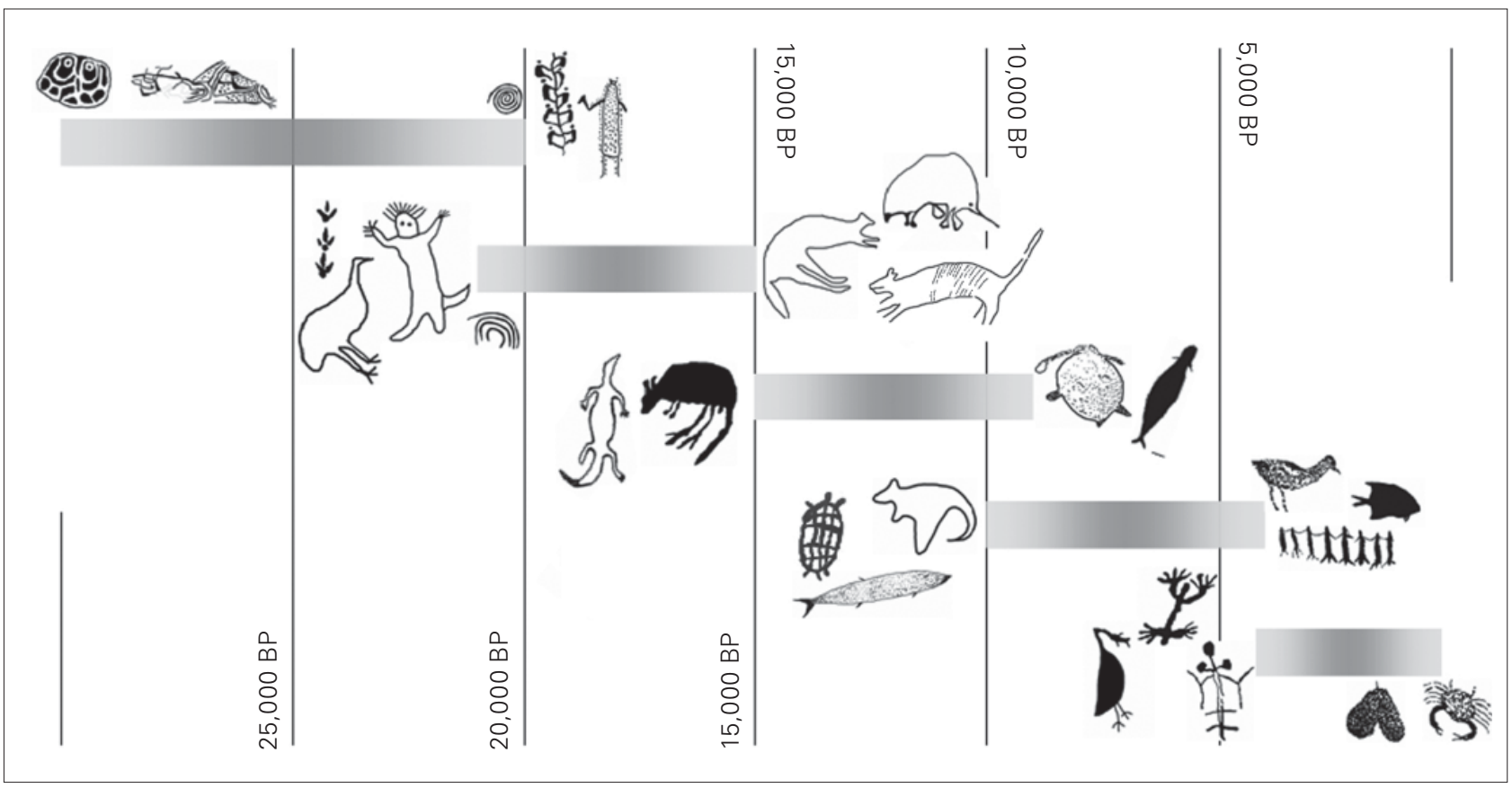

FIGURE 23

Suggested chronological sequence of the petroglyph phases.

evident, including an increase in their appearance on the islands off Dampier Island. However, apart from modern (within the last 50 years) additions to the rock art repertoire (Gunn 2007), nothing appears to have been added within the contact period (since European establishment in the region). This is likely a reflection of the devastation to traditional life effected by the events known as the Flying Foam Massacre that occurred in 1868 (Gara 1983; Dyson n.d.).

This paper proposes a sequence of rock art phases, based primarily on the extent of weathering of the engraved surface being indicative of relative age (Figure 23). The initiation of recorded art within the Dampier Archipelago is assumed to be concurrent with the earliest archaeological evidence for people in the region. Thus Phase 1 art is seen to date from approximately 25,000 BP and likely continued into the LGM (Phase 1: 25,000 $\mathrm{BP} \pm 5,000$ ). This is consistent with other archaeological evidence from the Pilbara. A significant change occurs in the heavily weathered rock art, in style, subject and situation. Ameliorating conditions following the LGM is the obvious contender. Phase 2 is regarded therefore as associated with a post LGM cultural tradition, commencing 18,000 $\mathrm{BP} \pm 3000$. Patterns in the degree of weathering and repatination are indicative of an extended period of art production. Again there is a marked change in the rock art, a period based on the absence of marine subjects most likely predates the formation of the coastal region of the Dampier Archipelago. Thus Phase 3 is regarded as in the period $12,000 \mathrm{BP} \pm 3000$. This is in the period associated with the middle range of patinated images. The later rock art phases are directly associated with the formation of the Dampier Archipelago and the importance of marine resources, with the first of the marine period art phases associated with the initial formation of a coastal environment (Phase 4: 7,000 BP \pm 3000 ). There is also a major change in a range of archaeological evidence, including rock art imagery, which points to a separate artistic tradition which developed and flourished after 4,000 BP (Phase 5).

In summary, the principal subject and style of images associated with each of the proposed rock art traditions are:

Phase 1. Pecked 'archaic faces', elaborate geometric designs, anthropomorphs incorporating geometric elements, 'dot-headed' human figures and simple birds and quadrupeds; Phase 2. Pecked and abraded large outline emus, macropods and pythons, outline human figures and large emu and macropod tracks;

Phase 3a. Pecked outline and intaglio images of birds, marsupials and reptiles, anthropomorophs and therianthropomorphs, simple geometric designs;

Phase 3b. Pecked intaglio stylised birds and macropods, dynamic grouped humans, simple and linear geometric designs;

Phase 4. Pecked outline and internal design marine fish and turtles, aquatic bird tracks, simple macropod tracks;

Phase 5a. Pecked and pounded, outline, internal 
design and intaglio turtles with eggs, other marine animals, bi-lobed/liver design, terrestrial fauna, stick figures, linked human row; humans with paraphernalia;

Phase 5b. Pecked, abraded, bruised and scratched, birds fish and stick figures, linear geometric elements, human figures with oversized hands and feet.

\section{CONCLUSION}

Over 30 years ago the rock art of the Dampier Archipelago was recognised as 'in a variety unparalleled elsewhere in the State' (Dix 1977: 280). Sylvia Hallam was not alone in contemplating a significant antiquity to this colossal corpus of Dampier petroglyphs; a newspaper headline ran 'rock carvings could be 15,000 years old' (Hamersley News 8 February 1973, p. 7). The by-line opens with 'One of the little-known benefits of Western Australia's recent mineral boom has been the discovery of a wealth of Aboriginal rock paintings and engravings'. Although detailed surveys and recording are still needed throughout Dampier Island and adjacent islands, it is not unreasonable to identify an age of greater than 20,000 BP and to postulate an even greater antiquity of some 30,000 years for the production of petroglyphs within the land forms that are now the Dampier Archipelago.

The sequence as outlined in this paper is based primarily on the degree of patination exhibited by the petroglyphs, and to a lesser extent by the associated mode of production. It deals with the general trends and motif classes; it does not cover the uncommon artistic embellishments and does not attempt to incorporate all motif forms. The sheer number and diversity of artistic expression evidence within the Dampier Archipelago means that there are unique styles and individual images that are outside the general range. However, it is this sheer quantity of rock art that enables the development of temporal indices in the absence of direct dating techniques.

Clear stylistic and thematic divisions are exhibited in the rock art, some certainly relating to changing environmental conditions. The art conventions of the five major phases might well relate to cultural traditions and to social and economic changes, reflecting broad, possibly regional, trends as well as echoing more general developments across Australia. Certainly there is a component of the art that, if not 'classic Panaramitee', is at least comparable to the 'Panaramitee' style. The distinct feature of the Dampier Archipelago is that high level production of silhouette figurative art is contemporary with the tracks and geometric element (cf. Franklin 2004).

It was the initial industrial developments on Dampier Island (now the Burrup Peninsula) that brought awareness of the wealth of rock art to people's attention back in the 1960s. The profusion of petroglyphs, coupled with the range of stylistic and subject variability set amongst a backdrop of stunning landforms and changed ecological conditions, places the Dampier Archipelago rock art a world apart and unique. It is a tragedy therefore that; 'No changes have been made to the original designation for industrialisation, the plans for which were made before the details of the cultural heritage were known' (Vinnicombe 2002: 13). The Western Australian Government continues to encourage industry to the area, a consequence of which is the destruction of rock art. There has been inadequate heritage management of the Dampier Archipelago, minimal funding and under-resourcing of relevant statutory bodies charged with cultural protection.

The rock art of the islands of the Dampier Archipelago deserves better. We have a place unique in Australia's petroglyphs, a location that during the period of human history went from a series of hills and ranges standing proud of a vast open plain to a series of near coastal islands. It is a place for which the very hardness of the rock has preserved the changing patterns of artistic endeavour over a period of several tens of millennia. While this is still only a preliminary study, it is clear that at least five significant artist phases, cultural traditions, existed with diagnostic trends and shifts through time from the elaborate 'archaic faces' to the human stick figures with over emphasised hands and feet, and from large outline petroglyphs of emus and kangaroos, to depictions of other animals, and finally smaller images of marine fish and crustaceans.

\section{ACKNOWLEDGMENTS}

I am indebted to a number of people who have commented on earlier drafts of this paper, especially Ben Gunn, Andy Collis, Caroline Bird and Iain Davidson. A fair number of other people have suffered the exposition of my musing out on the rocks themselves, their qualified acceptance - or at least not running away - has inspired me to put my thoughts to paper. I also acknowledge those Aboriginal custodians who themselves have shared their culture and concerns. Lastly I would like to acknowledge two great women of Western Australian archaeology, Sylvia Hallam and Pat Vinnicombe, both of whom have stood by their ethical principles and have assisted many in their own avenues of enquiry.

\section{REFERENCES}

Barnett, C. 2006. Hansard. Western Australia, Assembly, 9 March 2006, pp. 194-213.

Bednarik, R.G. (1979/80). The potential of rock patination analysis in Australian archaeology. The Artefact 4 (3\&4): 14-38, 5, (1\&2): 47-77. 
Bednarik, R.G. (2002). The survival of the Murujuga (Burrup) petroglyphs. Rock-art Research 19: 29-40.

Bednarik, R.G. (2006). Australian apocalypse: the story of Australia's greatest cultural monuments. Occasional AURA Publications no. 14, Melbourne.

Bradshaw, E. (1995). Dates from archaeological excavations on the Pilbara coastline and islands of the Dampier Archipelago, Western Australia. Australian Archaeology 41: 37-8.

Brown, S. (1983). Incised rock engravings and fat-tailed macropod motifs, Pilbara, W.A. (pp. 185-98). In: Smith, M. (ed.), Archaeology at ANZAAS 1983. Western Australian Museum: Perth.

Brown, S. (1987). Towards a prehistory of the Hamersley Plateau. Occasional Papers in Prehistory 6. Department of Prehistory, Research School of Pacific Studies, Australian National University: Canberra.

Chaloupka, G. (1984). From palaeoart to casual paintings: the chronological sequence of Arnhem Land Plateau rock art. Northern Territory Museum of Art and Sciences Monograph Series no. 1: Darwin.

Chaloupka, G. (1992). Journey in time. Reed: Chatswood, NSW.

Clarke, J. (1978). Rock patination and the age of Aboriginal engravings at Dampier W.A. Unpublished report to the Department of Aboriginal Sites, Western Australian Museum: Perth.

Department of Aboriginal Sites (1984). Dampier Archaeological project: survey and salvage of Aboriginal sites on portion of the Burrup Peninsula for Woodside Off-shore Petroleum Pty. Ltd. Unpublished report, Department of Aboriginal Sites, Western Australian Museum, Perth.

Daniel, D. (1990). Thalu sites of the west Pilbara. Department of Aboriginal Sites, Western Australian Museum: Perth.

David, B. (2002). Landscapes, rock-art and the Dreaming. Leicester University Press: London.

Dragovich, D. (1986). Minimum age of some desert varnish near Broken Hill, New South Wales. Search 17: 149-51.

Dragovich, D. (2000). Rock engraving chronologies and Accelerator Mass Spectrometry radiocarbon Age of desert varnish. Journal of Archaeological Science 27: 871-876.

Dyson, M.R. (n.d.). Flying Foam Massacre: a grey area in the history of the Burrup Peninsular. Self published, Karratha CAD Centre.

Dix, W. (1977). Facial representations in Pilbara rock engravings (pp. 277-86). In: Ucko, P.J. (ed.), Form in indigenous art. Australian Institute of Aboriginal Studies: Canberra.

Dorn, R.I. (2001). Chronometric techniques: engravings (pp. 167-89). In: D. S. Whitley (ed.), Handbook of rock art research. Altamira Press: Walnut Creek, California.

Edwards, R. (1966). Comparative study of rock engravings in south and central Australia. Transactions of the Royal Society of South Australia 90: 33-38.

Edwards, R. (1968). Prehistoric rock engravings at Thomas Reservoir, Cleland Hills, western central Australia. Records of the South Australian Museum 15: 647-670.

Flood, J. (1997). Rock art of the Dreamtime. Angus and Robertson: Hong Kong.
Franklin, N.R. (2004). Explorations of variability in Australian prehistoric engravings. BAR International Series 1318. British Archaeological Reports: Oxford.

Gara, T.J. (1983). The Flying Foam Massacre: an incident on the north-west frontier, Western Australia (pp. 86-94). In: Smith, M. (ed.), Archaeology at ANZAAS 1983. Western Australian Museum: Perth.

Gunn RG. (2003). Parker Point Upgrade Project, Dampier, Western Australia: Archaeological Survey. Unpublished report, Hamersley Iron.

Gunn RG. (2004). Parker Point Upgrade Project, Dampier, Western Australia: Archaeological Survey. Unpublished report, Hamersley Iron.

Gunn R.G. (2007). Sketching the surface: scratched petroglyphs at Parker Point, Dampier, Western Australia (pp. 35-51). In: Chenna Reddy, P. (ed.), Exploring the mind of ancient man. Research India Press: New Delhi.

Hickman, A.H. (2001). Geology of the Dampier 1: 100,000 Sheet. Geological survey of Western Australia, Department of Minerals and Energy: Perth.

Lewis, D. (1988). The rock paintings of Arnhem Land, Australia: social, ecological and material culture change in the post-glacial period. BAR International Series 415. British Archaeological Reports: Oxford.

Lewis, D. and McClausland, B. (1987). Engraved human figures and faces from Wardaman country, eastern Victoria River District, Northern Territory. Australian Aboriginal Studies 1987/1: 67-79.

Lewis, D. and Rose, D. (1988). The shape of the Dreaming: the cultural significance of Victoria River rock art. Aboriginal Studies Press: Canberra.

Lorblanchet, M. (1983). Chronology of the rock engravings of Gum Tree Valley and Skew Valley near Dampier, Western Australia, WA (pp. 180-84). In: Smith, M. (ed.), Archaeology at ANZAAS 1983. Western Australian Museum: Perth.

Lorblanchet, M. (1992). The rock engravings at Gum Tree Valley and Skew Valley, Dampier, Western Australia: chronology and function of sites (pp. 39-59). In: MacDonald, J. and Haskovic, I.P. (eds), State of the art 1983. Occasional AURA Publications no. 6, Melbourne.

Lorblanchet, M. and Jones, R. (1979). Les premières fouilles à Dampier, (Australie occidentale), et leur place dans l'ensemble australien (The first excavations at Dampier, [Western Australia], and their place in the Australian assemblage). Bulletin de la Société Préhistorique Française 76: 463-487.

McCarthy, F.D. (1961). The rock engravings of Depuch Island, north-west Australia. Records of the Australian Museum 25: 121-148.

McDonald, J. (2005). Archaic faces to headdresses: the changing role of rock art across the arid zone (pp. 116-141). In: Veth, P., Smith, M. and Hiscock, P. (eds), Desert peoples: archaeological perspectives. Blackwell: Carlton.

McDonald, J. and Veth, P. (2005). Desktop assessment of scientific values for Indigenous cultural heritage on the Dampier Archipelago, Western Australia. Unpublished report to the Department of Environment and Heritage: Canberra.

Marwick, B. (2002). Inland Pilbara archaeology: a study of variation in Aboriginal occupation over time and space on the Hamersley plateau. M.A. thesis, University of Western Australia: Nedlands. 
Maynard, L. (1979). The archaeology of Australian Aboriginal art (pp. 83-110). In: Mead, S.M. (ed.), Exploring the visual art of Oceania. University Press of Hawaii: Honolulu.

Morwood, M.J. (2002). Visions from the past. Allen and Unwin: Crows Nest, Australia.

Mountford, C. and Edwards, R. (1963). Rock engravings of Panaramitee Station, north-eastern South Australia. Transactions of the Royal Society of South Australia 86: 131-46.

Mulvaney, J. and Kamminga, J. (1999). Prehistory of Australia. Allen and Unwin: St. Leonards, Australia.

Mulvaney, K. (1982). Desert vanish. Unpublished report, Department of Aboriginal Sites, Western Australian Museum: Perth.

Mulvaney, K. (2009). Dating the Dreaming: extinct fauna in the petroglyphs of the Pilbara region, Western Australia. Archaeology in Oceania (Supplement) 44: 40-48.

Nobbs, M. and Dorn, R. (1993). New surface exposure ages for petroglyphs from Olary Province, South Australia. Archaeology in Oceania 28: 18-39.

Roberts, R.G., Jones R., and Smith M.A., 'Thermoluminescence dating of a 50,000 year-old human occupation site in northern Australia', Nature, 1990, vol. 345, pp. 153-156.

Rosenfeld, A., Horton, D. and Winter, J. (1981). Early man in North Queensland. Terra Australis 6. Department of Prehistory, Research school of Pacific Studies, Australian National University: Canberra.

Rosenfeld, A. and Smith, M.A. (2002). Rock-art and the history of Puritjarra rock shelter, Cleland Hills, Central Australia. Proceedings of the Prehistoric Society 68: 103-124.

Sales, K. (1992). Ascent to sky: a shamanic initiatory engraving from the Burrup Peninsula, north-west Western Australia. Archaeology in Oceania 27: 22-36.

Smith, C. (1992). Colonising with style: reviewing the nexus between rock art, territoriality and the colonisation and occupation of Sahul. Australian Archaeology 34: 34-42.

Smith, M.A., Williams, A.N., Turney, C.S.M. and Cupper, M.L. (2008). Human environmental interactions in Australiann drylands: exploring time series analysis of archaelogical recods. The Holocene 18: 389-401

Tacon, P., Fullagar, R., Ouzman, S. and Mulvaney, K. (1997). Cupule engravings from Jinmium-Granilpi (northern Australia) and beyond: exploration of a widespread and enigmatic class of rock markings. Antiquity 71: 942-965.
Thorley, P. (2004). Rock-art and the archaeological record of indigenous settlement in Central Australia. Australian Aboriginal Studies 2004/1: 79-89.

Veth, P. (1993). Islands in the interior: the dynamics of prehistoric adaptations within the arid zone of Australia. University of Michigan: Ann Arbor.

Veth, P. (2005). Between the desert and the sea: archaeology of the Western Desert and Pilbara regions, Australia (pp. 132-41). In: Smith, M. and Hesse, P. (eds), $23^{\circ} \mathrm{S}$ Archaeology and environmental history of the southern deserts. National Museum of Australian Press: Canberra.

Veth, P., Bradshaw, E., Gara, T., Hall, N., Haydock, P. and Kendrick, P. (1993). Burrup Peninsula Aboriginal Heritage Project. Unpublished report to the Department of Conservation and Land Management: Perth.

Veth, P., Gara, T. and Kendrick, P. (1994). The Aboriginal face of rock-art on the Burrup Peninsula (pp. 213-226). In: Sullivan, M., Brockwell, S. and Webb, A. (eds), Archaeology in the north. North Australia Research Unit (A.N.U.): Darwin.

Vinnicombe, P. (1987). Dampier Archaeological Project: resource document, survey and salvage of Aboriginal sites, Burrup Peninsula, Western Australia. Western Australian Museum: Perth.

Vinnicombe, P. (2002). Petroglyphs of the Dampier Archipelago: Background to Development and Descriptive Analysis. Rock-art Research 19: 1-28.

Virili, F.I. (1977). Aboriginal sites and rock-art of the Dampier archipelago, Western Australia: a preliminary report (pp. 439-451). In: Ucko, P.J. (ed.), Form in indigenous art. Australian Institute for Aboriginal Studies: Canberra.

Walsh, G.L. (1994). Bradshaws: ancient rock paintings of north-west Australia. Edition Limitée: GarougeGeneva.

Watchman, A.L. and Jones, R. (1998). Dating rock images in the tropical monsoon region of northern Australia. Australian Aboriginal Studies 1998/2: 64-70.

Withnell, J.G. (1901). The customs and traditions of the Aboriginal natives of Western Australia. Private Printing: Roebourne, Australia.

Wright, B.J. (1968). Rock art of the Pilbara region, north-west Australia. Australian Institute of Aboriginal Studies: Canberra.

MANUSCRIPT RECEIVED NOVEMBER 2006; ACCEPTED MAY 2008. 